\title{
International trade and consumption-based carbon emissions: evaluating the role of composite risk for RCEP economies
}

\author{
Taimoor Hassan $^{1} \cdot$ Huaming Song ${ }^{1} \cdot$ Dervis Kirikkaleli $^{2}$ \\ Received: 20 May 2021 / Accepted: 20 July 2021 / Published online: 13 August 2021 \\ (C) The Author(s), under exclusive licence to Springer-Verlag GmbH Germany, part of Springer Nature 2021
}

\begin{abstract}
To tackle the issue of climate change and environmental degradation debates regarding carbon neutrality is on the rise. Regional Comprehensive Economic Cooperation (RCEP), the leading trading union, covers nearly third of global economy, world population, is responsible for thirty percent of global trade and global gross domestic product. The existent study tests the impact of financial, economic, political, and composite risk on consumption-based carbon dioxide emissions $\left(\mathrm{CCO}_{2}\right)$ in selected RCEP economies during the period of 1990 to 2020 . The empirical analysis consists of cross-sectional dependence, slope heterogeneity, cross-sectional augmented panel unit root test, Westerlund cointegration, second-generation cross-section augmented autoregressive distributed lags model (CS-ARDL), and panel causality test. Further, we explore the role of imports, renewable energy supply, exports, and gross domestic product per-capita on $\mathrm{CCO}_{2}$. The empirical results suggest that the less political risk help to mitigate while the lower financial, economic, and composite risk increase $\mathrm{CCO}_{2}$ emissions in selected RCEP economies. Moreover, exports and renewable energy supply show mitigating effect, whereas imports show upsurge in $\mathrm{CCO}_{2}$. Additionally, a bidirectional causality exists between exports and $\mathrm{CCO}_{2}$, imports and $\mathrm{CCO}_{2}$, GDP per-capita and $\mathrm{CCO}_{2}$, political risk and $\mathrm{CCO}_{2}$, and renewable energy and $\mathrm{CCO}_{2}$ emissions, while a one-way causality from financial risk, composite risk, and economic risk to $\mathrm{CCO}_{2}$. Renewable energy supplies along with the improvement in sub-components of political risk, for instance, corruption, government stability, would help to effectively tackle the issue of $\mathrm{CCO}_{2}$ emissions.
\end{abstract}

Keywords Economic risk · Consumption-based carbon emissions · CS-ARDL technique $\cdot$ Regional Comprehensive Economic Cooperation $\cdot$ Exports $\cdot$ Imports $\cdot$ Renewable energy supply

Responsible Editor: Eyup Dogan

Huaming Song

huaming@njust.edu.cn

Taimoor Hassan

taimoor@njust.edu.cn

Dervis Kirikkaleli

dkirikkaleli@eul.edu.tr

1 Department of Management Science and Engineering, School of Economics and Management, Nanjing University of Science and Technology, Nanjing 210094, China

2 Faculty of Economic and Administrative Sciences, Department of Banking and Finance, European University of Lefke, Lefke, Northern Cyprus, TR-10 Mersin, Turkey

\section{Introduction}

Carbon neutrality target can be achieved through many ways in Regional Comprehensive Economic Partnership (RCEP) economies. The level of international trade statistics is on the rise since the last few decades; as the contribution of international trade has grown from $27.3 \%$ in 1970 to $60.3 \%$ of gross domestic product (GDP) in 2019 according to World Bank (WB). During the last sixty-year period, trade activity expanded at even faster pace than it did during the first period of globalization. The comparative advantage in productive capabilities of some countries over the others is the one important reason of expansion in international trade. Commonly, such drastic expansions are often achieved on the cost of environmental degradation and that's why international trade is growingly being taken into consideration in environment pollution or climate change discussions (Hasanov et al. 2018; Heil and Selden 2001; Tamiotti 2009). However, economists argue that international trade practices are generally 
considered as a determinant of efficient economic system; which helps to correct market failures, strengthen the potential of globalization, and boost foreign exchange reserve. Meanwhile, the earnings from globalization will enhance income and productivity and as an outcome of technique and scale effect, environmental pollution will fall (Cole and Elliott 2003). At a certain level of income, trade practices are environment friendly and help to mitigate certain measures $\left(\mathrm{SO}_{2}\right)$ of environmental pollution (Frankel and Rose 2005). Trade impact environmental pollution through capital labor and environmental regulation effect and found to have a beneficial effect on environment in OECD economies (Managi et al. 2008). Conversely, some concerns that rich economies limit their production-based emissions due to stringent environmental policies but in fact, they are welcome at other low-income economies with relaxed environmental regulations - this situation is known as Carbon-Leakage claimed by "Pollution-Heaven Hypothesis" (Bednar-Friedl et al. 2012; Cole 2004; Eskeland and Harrison 2003; Hasanov et al. 2018; Liddle 2018).

So far, emissions manufactured inside sovereign boundaries of a nation (territory or production-based) has gained attention whereas, relatively limited studies focus on trade adjusted carbon emissions (consumption-based emissions) (Ali et al. 2020; Hasanov et al. 2018; Liddle 2018; Spaiser et al. 2019). However, the fact that rich economies emit less emissions compared to industrial economies due to comparative advantage in service, technology and knowledge-based sectors is not comprehending in earlier studies. In this scenario, the goods produced by low-income economies are finally consumed in rich economies, while the carbon emissions of these goods are assigned to the low-income economies (Peters and Hertwich 2008; Scott and Barrett 2015).

Recent literature on highly debated Environmental Kuznets curve claims that after reaching a certain threshold level of income, economies tend to reduce their carbon emissions (Acaravci and Ozturk 2010; Cole 2004). But meanwhile, expansion in international trade practices occurs in order to meet their growing demand from low-income economies (Davis and Caldeira 2010; Rothman 1998). Therefore, the inverted-U shaped environmental Kuznets curve does not hold significantly true for consumption-based carbon emissions; because rise in income level is associated with the growing demand for international trade which encourages production of goods and results in more emissions (Cole and Elliott 2003; Frankel and Rose 2005; Managi et al. 2008). Consequently, considering the inverted-U shaped EKC, it seems that the fall in emissions with rise in income level in one country (production-based emissions) leads to emissions in other countries. In order to comprehensively capture such carbon emissions appropriately, one should consider consumption-based carbon emissions; more suitable to cover the entire carbon chain and significant to realize the global struggle for alleviating the growing level of emissions (Fernández-Amador et al. 2017; Liddle 2018). Additionally, comparative analyses of production-based carbon emissions to consumption-based carbon emissions reveal that international trade has an insignificant impact on the former but significant on the later one (Al-mulali and Sheau-Ting 2014; Knight and Schor 2014; Liddle 2018).

Previous literature on trade-emissions linkage results in contradictory results; some concludes trade as tool of economic growth that helps to sustain environmental pollution by efficient allocation of resources. While others argue that trade practices deteriorate environmental quality and promote emission beyond borders which is often neglected (Al-Mulali and Ozturk 2015; Balsalobre-Lorente et al. 2017; Nathaniel and Khan 2020). Most of the previous studies incorporated export and import aggregately as a variable of trade openness in their investigation while limited studies consider the disaggregate impact of import and export on consumption-based emissions (Khan et al. 2020; Knight and Schor 2014; Liddle 2018; Ozturk and Acaravci 2013; Shahbaz et al. 2017; Shahzad et al. 2017).

Recent literary studies on environmental degradation discover a significantly positive impact of corruption on emissions while anti-corruption campaign and none or few numbers of corrupt officials limit this adverse effect (Chen et al. 2018; Zhou et al. 2020), while others employed institutional quality index (rule of law, sum of corruption, and bureaucratic quality) to observe its possible impact on environmental quality (Ali et al. 2019). However, to the best of our knowledge, no empirical study till date has investigated the influence of economic, political, financial, and composite risk on consumption-based carbon along with the role of renewable energy in selected RCEP economies.

\section{Overview of trade in RCEP selected economies}

The RCEP has formed the world largest trading bloc, casing almost a third of the global economy. RCEP economies represent 2.3 billion i.e.; $30 \%$ of the world's population along with similar percentage for global trade and global gross domestic product (GDP) visualized in Fig. 1. Five RCEP countries (Australia, China, Indonesia, Japan, and South Korea) are among the world's top 20 largest economies and members of Group of 20 (G20).

RCEP negotiations were launched in November 2012 and the agreement was signed on 15 November 2020 by 10 Southeast Asian nations (ASEAN includes Brunei, Cambodia, Indonesia, Laos, Malaysia, Myanmar, Philippines, Singapore, Thailand and Vietnam) and five of ASEAN's free trade agreement partners (Australia, China, Japan, New Zealand and Republic of Korea).

The agreement between signatory economies indicates a positive move forward for free-trade and multilateralism in the Asia-Pacific region, particularly in the time of uncertainty 


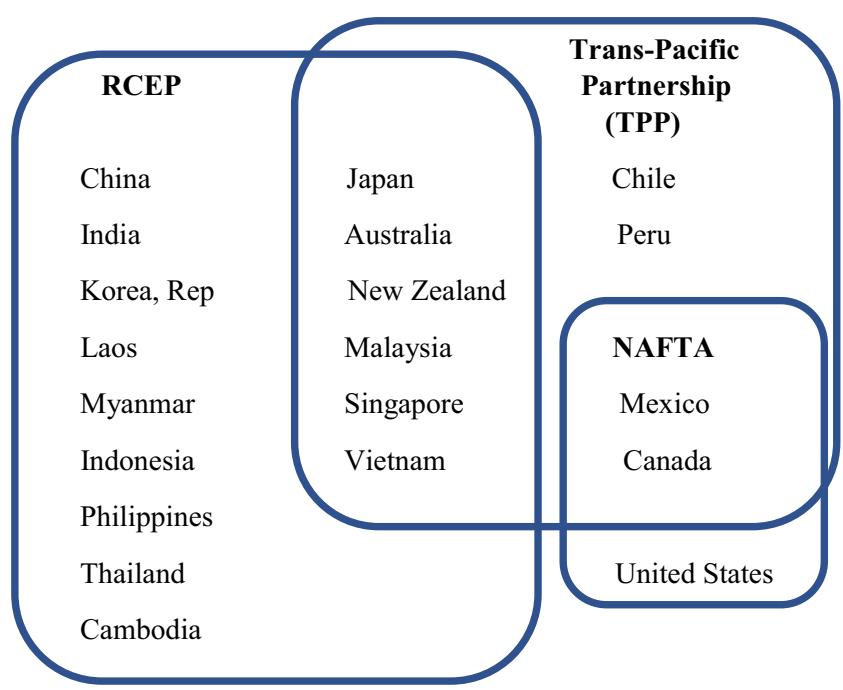

Fig. 1 RCEP economies comparison with other blocs

and economic strain caused by the COVID-19 pandemic. Meanwhile, less aspiring than Comprehensive and Progressive Agreement for Trans-Pacific Partnership (CPTPP), the RCEP bloc formation lays a foundation for deeper cooperation in the future as it brings together countries that have yet to conclude trade agreement with each other, as it is China's first multilateral trade deal and the first trade agreement between, Japan, China, and South Korea. The deal aims to eliminate trade frictions (90\% of tariffs) and liberalize goods and services trade, while making advances in areas of competition policy, investment, intellectual property right (IPRs), economic and technological cooperation and government procurement. Conclusively, it is claimed that in the short run, the contribution of RCEP to the trade and income in the region will be rather modest, due to the fact that over $70 \%$ of trade within the ASEAN region enjoy zero tariffs (Asian Development Bank 2020). However, connecting ASEAN to the five big economies (China, South Korea, Australia, Japan, New Zealand) will more likely to reshape the future of trade in Asia and in the world.

The last few decades have witnessed the emerging economies in Asia-Pacific region being the new engine of global economic growth, accounting $60 \%$ of global economic growth (Asian Development Bank 2017). Along with significant growth potential, issues concerning energy security in trade-environment nexus and environment-growth nexus are increasingly important. Since 1990, an average annual $2 \%$ of growth rate is recorded for renewable energy sources, which is slightly above than total energy supply (TES) $1.8 \%$, growth rate of the world (IEA).

According to 2018 statistics, TES of the world was 14,282 Mtoe, of which $13.5 \%$ was produced from renewable energy sources (IEA). How to safeguard energy supply and at what percentage of (renewable and non-renewable) energy could be supplied in order to mitigate environmental degradation have turned into top priorities of government and important factors in achieving sustainable development goals.

RCEP, the largest trading bloc in the world, covering $3^{\text {rd }}$ of global economy responsible for $30 \%$ of global GDP reported in Fig. 2, aims to eliminate $90 \%$ of tariffs gradually in the region. Therefore, it would be interesting to investigate empirically the impact of (i) Economic, Political, Financial and Composite Risk; (ii) Renewable energy supply; and (iii) disaggregated export and import on the consumption-based carbon emission in RCEP selected economies. The 11 economies namely Australia, Japan, Korea, Rep., New Zealand, China, Indonesia, Malaysia, Philippines, Singapore, Thailand, and Vietnam are selected solely based on availability of the data. In order to obtain robust results, we developed five different models for the empirical estimation procedure. The cointegration relationship among observed variables is observe by employing Westerlund panel cointegration (2007) technique. We examine the long-run and short-run relationship among the explanatory variables in each model over cross-sectional augmented autoregressive distributive lag (CS-ARDL) methodology. The empirical analyses are further advance by pairwise Dumitrescu-Hurlin panel causality (2012) test. We find that the lower the Financial, Economic and Composite risk, the more consumption-based $\mathrm{CO}_{2}$ emissions in long-run as well as in short-run in the selected RCEP economies. Interestingly, less political risk is related with less consumption-based $\mathrm{CO}_{2}$ emissions, while increase in renewable energy supply significantly decreases consumption-based $\mathrm{CO}_{2}$ emissions. Furthermore, exports decrease while imports and GDP per-capita increase consumption-based $\mathrm{CO}_{2}$ emissions both in long-run and short-run in selected economies.

The current study contributes to existing $\mathrm{CO}_{2}$ emissions literature in several ways. (I) To the best of our knowledge, this is the first study that investigates the impact of economic risk, political risk, financial risk, and composite risk on consumption-based carbon emissions in selected RCEP economies. The 11 selected RCEP economies alone account for around 29\% of world's exports (due to abundance of natural resources in Australia or cheap labor and lower production cost in China), adding to their foreign exchange reserve from huge export potentials that enables them to expand their importing capacity. Second after the European Union (EU) (28.2\%), selected RCEP economies account for $25 \%$ of global import. The growing import capacity may lead to rising consumption-based carbon emissions and would be interesting to investigate the issue empirically by considering a panel of 11-RCEP economies from 1990 to 2020. (II) Also, it is among the first studies to investigate the disaggregated impact of export and import on consumption-based carbon emissions rather than choosing export and import collectively as trade openness, and (III) to consider the role of renewable energy supply in mitigating consumption-based $\mathrm{CO}_{2}$ emissions. 
Fig. 2 Share of RCEP in global GDP 2020

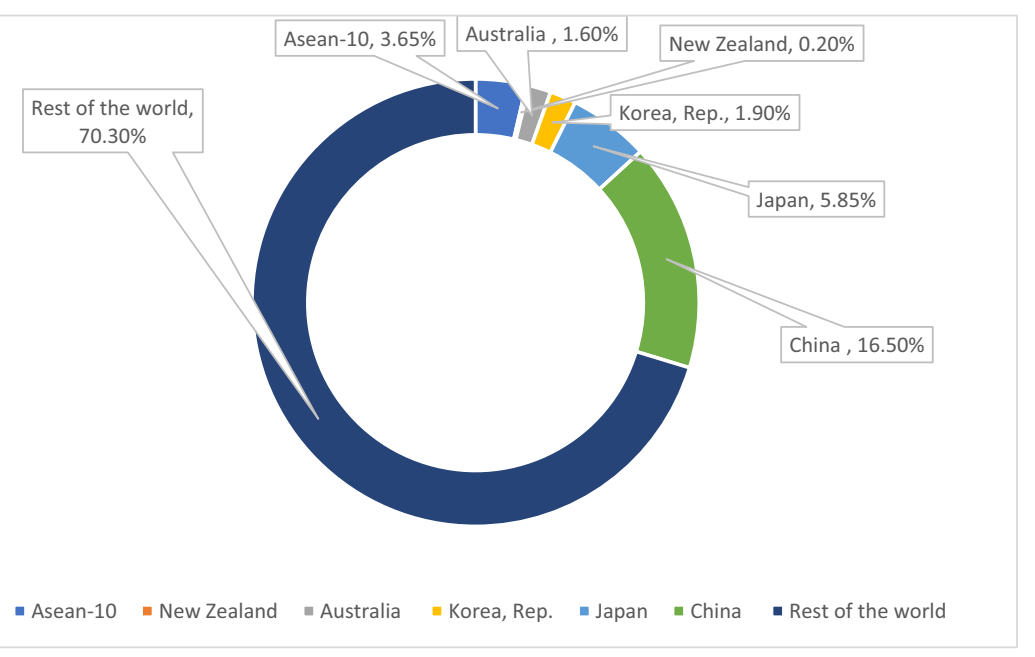

Finally, the findings of the study may be useful for the policies mitigating environmental degradation and climate change since consumption-based carbon emissions captured the emissions along the entire carbon chain rather than emissions produced within a sovereign border of a nation (production-based/territorial-based carbon emission).

In order to observe whether an economy is a net emission exporter or importer, Table 1 shows average ratios of consumption-based carbon emission vs. territorial-based carbon emissions for selected RCEP economies. The countries with $\mathrm{CCO}_{2} / \mathrm{TCO}_{2}$ ratio less than 1 are net emission exporters while in case of $\mathrm{CCO}_{2} / \mathrm{TCO}_{2}$ ratio greater than 1 are recorded as net emission importer. The difference of $\mathrm{CCO}_{2}-\mathrm{TCO}_{2}$ states that the country is a net emission exporter if the resulted value is negative while net emission importer in case of a positive value. Due to the comparative advantages in production and huge trade capabilities, Australia, China, Indonesia, Malaysia, and Thailand are considered as net emission exporters.

Table 1 Average ratios of Consumption $\left(\mathrm{CCO}_{2}\right)$ vs. Territorial $\left(\mathrm{TCO}_{2}\right)$ carbon emission

\begin{tabular}{llll}
\hline Country & $\mathrm{CCO}_{2} / \mathrm{TCO}_{2}$ & $\mathrm{CCO}_{2}-\mathrm{TCO}_{2}$ & Decision \\
\hline Australia & 0.91243 & -32.0165 & Net emission exporter \\
Japan & 1.173042 & 212.5201 & Net emission importer \\
Korea, Rep. & 1.126699 & 60.36552 & Net emission importer \\
New Zealand & 1.069039 & 2.298552 & Net emission importer \\
China & 0.865029 & -829.717 & Net emission exporter \\
Indonesia & 0.967903 & -12.0187 & Net emission exporter \\
Malaysia & 0.928919 & -11.9568 & Net emission exporter \\
Philippines & 1.240515 & 19.57598 & Net emission importer \\
Singapore & 2.199455 & 58.65211 & Net emission importer \\
Thailand & 0.954745 & -9.23329 & Net emission exporter \\
Vietnam & 1.039428 & 4.0369 & Net emission importer \\
\hline
\end{tabular}

Note: Authors own calculation based on data gleaned from Global Carbon Atlas database

\section{Literature review}

Where globalization and rapid economic development result in interconnectedness among economies along with better standard of living, environmental economists worry about the downside of such activities. Due to recent focus on climate change and environmental degradation, advanced economies commit to limit their carbon emissions (territorial/ production-based emissions) either by engaging in low carbon emissions activities or moving to greener production (Renewable energy). Meanwhile, to feed the growing demands of a nation, advanced economies import most carbon intensive products from economies with relaxed environmental regulations (Developing economies) resulting in less territorial/production-based emissions but more consumption-based carbon emissions.

Recently, a number of studies investigated various determinants of environmental degradation in term of carbon emissions. For instance, Liddle (2018) examined the effect of trade on consumption and territorial-based carbon emissions for a panel of 102 countries from 1990 to 2013. While considering disaggregated trade (export and import individually), the results from Common Correlated Effect Mean Group (CCEMG) estimation technique revealed that export decreased consumption-based carbon emissions while imports along with Gross Domestic Product (GDP) surged emissions. Furthermore, the author found that share of industry and fossil fuel increased consumption-based carbon emissions while GDP caused positively and significantly but exports and imports negatively and insignificantly such emissions.

Followed by a similar study, Liddle (2018) inquired a panel of 20 selected Asian economies and used the prior mentioned time period and estimation technique. The findings revealed that trade insignificantly caused territory-based carbon emissions whereas it is found significant for consumption-based carbon emissions. 
A study by Safi et al. (2021) examined the impact of financial instability on consumption-based carbon emissions in E-7 economies (Seven Emerging Economies) from 1995 to 2018 by employing Panel Cointegration and Cross-sectional Augmented ARDL (CS-ARDL) methodologies. The results confirmed both the short- and long-run relationship among the observed variables: consumption-based carbon emissions, financial instability, imports, exports, technological innovation, and economic growth. The finding revealed that financial instability, exports and technological innovations significantly reduce consumption-based carbon emissions where imports and economic growth (GDP) increased the emissions both in short- and long-run.

Hasanov et al. (2018) modeled both consumption and production-based carbon emissions by applying cointegration and error correction modeling technique to a panel of nine oil-exporting economies from 1995 to 2013. The author found that $1 \%$ increase in exports and imports per capita results in about $0.6-0.8 \%$ decrease and $0.3-0.4 \%$ rise in consumption-based carbon emissions per capita, respectively. Furthermore, a $0.5-0.8 \%$ increase found significantly in consumption-based carbon emissions per capita with a $1 \%$ rise in GDP per capita. The study revealed that imports per capita insignificantly affect production/territorial-based emissions per capita.

Chen et al. (2018) employed generalized method of moment (GMM) for a panel data of 30 provinces in China from 1998 to 2012 in order to observe the impact of environmental regulations, shadow economy, and corruption on environmental quality. The author mentioned interesting results; strict environmental regulation is not associated with effectively reduction of environmental pollution (Production-based carbon emissions) due to immoderate level of corruption and shadow economy during the sampled period. However, the results also found that stringent environmental regulations along with a moderate level of shadow economy and confined number of corrupt officials significantly reduced environmental pollution.

Similarly, Zhou et al. (2020) found that the anti-corruption campaign by the Chinese government since 2013 significantly lessened the air pollution (PM2.5) level by $20.3 \%$ observing city-level data in China from 2009 to 2016 with difference-in-difference analysis (DID). The mechanism analysis in the study indicated that such pollution reduction results could be accomplished partly through strict environmental regulations and rapid economic development.

More recently, Hasanov et al. (2021) examined consumption-based carbon emissions by applying panel cointegration and CS-ARDL techniques to a panel of BRICS economies (Brazil, Russia, China, India, South Africa) over the period of 1990-2017. The results reported that technological progress, renewable energy consumption and export's magnitude played a significant role in reduction of carbon emissions, while GDP and value/size of import enhanced carbon emissions.

Exploring the sectoral level data of electricity consumption, electricity prices and real gross domestic product for Pakistan over the period 1970-2018, Abbasi et al. (2021a) employed Johansen Co-integration and Vector Error Correction Model (VECM). The study suggests that, as an agriculture-based economy, decrease in electricity prices increases electricity consumption and leads to a waste of energy.

By considering a panel of top 10 carbon emitter countries (Brazil, China, Germany, India, Indonesia, Japan, South Korea, Mexico, Russian federation and USA) over the period 1990-2017, Ali et al. (2020) applied Westerlund cointegration and CS-ARDL procedure. The author confirmed the significant role of exports, renewable energy consumption and environment friendly innovations in lowering consumption-based carbon emissions. Meanwhile, rise in imports and GDP found to boost such emissions.

Utilizing data of 35 Annex B countries (Signatory nations to the Kyoto Protocol) over the period 1990-2015 (Karakaya et al. 2019) tested the validity of environmental Kuznets Curve for both consumption and territorial/production-based emissions. Cross-sectional regression results supported the presence of EKC hypothesis as emissions fall after a certain threshold period of income. However, no evidence of EKC hypothesis found true for consumption-based carbon emissions in the Annex B countries.

Similarly, Işik et al. (2020) checked the authenticity of the EKC hypothesis for seven G7 economies over the period of 1995-2015. The empirical findings from panel bootstrap cointegration test and augmented mean group (AMG) report that except France, tourism-induced EKC hypothesis is not valid for all G7 economies. Furthermore, renewable energy consumption alleviates $\mathrm{CO}_{2}$ emissions in France, Italy, UK and the USA, whereas, tourism increases $\mathrm{CO}_{2}$ emissions of Italy.

Considering an annual data set from the year 1961 to 2014 for Turkey, Köksal et al. (2020) checked the validity of Environmental Kuznet Curve (EKC) hypothesis and the role of shadow economy on environmental degradation. The findings revealed the confirmation for EKC hypothesis and shadow economies as a long term and significant driver of environmental pollution in Turkey. Moreover, financial development and trade openness further degrade the environmental quality whereas, urbanization does not significantly report any such impact on environmental quality.

Similarly, Farhani et al. (2014) checked if EKC holds true for 10 MENA economies by using Panel Vector Error Correction Model (PVECM), Fully Modified Ordinary Least Square (FMOLS) and Panel Dynamic Ordinary Least Squares (PDOLS). The author found that income decreased while trade openness significantly increased carbon emissions. 
Considering the asymmetric relationship of renewable energy consumption, non-renewable energy, and terrorism on economic growth of Pakistan from 1970 to 2018, Abbasi et al. (2020) applied nonlinear autoregressive distributed lag (NARDL) and the finding revealed that renewable energy consumption along with better law and order situation play a vital role in economic growth of Pakistan.

Al-Mulali et al. (2016) also inquired EKC hypothesis along with the role of renewable energy consumption in seven selected regions (The Americas, Western Europe, East Asia \& the Pacific, East Europe and Central Asia, North Africa, Middle East, South Asia and Sub-Saharan Africa) over the period 1980-2010. The results from dynamic ordinary least square (DOLS) and vector error correction model Granger causality found that renewable energy reduced carbon emissions in East Asia and the Pacific, Western Europe, Central \& Eastern Europe, South Asia and the Americas while no significant effect on carbon emissions in Middle East, North Africa and Sub-Saharan Africa. Furthermore, the findings revealed that EKC hypothesis holds true only for the regions where renewable energy consumption has significant effect on carbon emissions.

To explore the contribution of the financial system and its efficiency in demand for renewable energy in 36 OECD economies, Köksal et al. (2021) employed system-GMM model and the findings revealed that financial system may promote renewable energy demand but the coefficients of financial system efficiency does not hold true to encourage renewable energy demand in OECD states. Based on the study, the overall finding suggests that financial development factors are imperfectly associated to the renewable energy demand of the OECD states.

In parallel, Katircioglu et al. (2021) investigated and compared the role of financial systems in energy demand for developed and developing economies over the period of 2000-2015. The empirical findings of autoregressive distributed lag model (ARDL) revealed that in developed economies, money supply, GDP, trade, and $\mathrm{CO}_{2}$ are responsible for the rise in the demand of energy, whereas in developing economies, it is the domestic credit, FDI, trade and $\mathrm{CO}_{2}$ which cause a rise for demand in the energy. Comparing the factors affecting the demand for energy, the study mentioned that money supply significantly increases energy demand in developed economies, whereas in developing economies, domestic credit causes an apparent rise in demand for energy.

Al-mulali and Sheau-Ting (2014) considered a large data set consisting of 189 countries from six different regions in order to explore several bi-variate relationships over the period 1990-2011. The authors employed PFMOLS technique to observe bi-directional long-run relationships between trade-energy, trade-carbon emissions, exports-energy consumption, exports-carbon emissions, imports-energy consumption and imports-carbon emissions. The panel results explained that except Eastern Europe, all the regions confirmed a long-run positive relationship between trade variables-energy consumption and between trade variable-carbon emissions. The country level results confirmed that $75 \%$ of countries indicate a bi-directional positive long-run relationship between trade variables, energy consumption and carbon emission while $7 \%$ of the economies exhibited negative long-run relationship, the other $7 \%$ showed no significant relationship while the remaining $11 \%$ of countries reported mixed results.

Considering the determinants of economic growth in Pakistan, Abbasi et al. (2021b) investigated the influence of energy consumption, energy prices, industrial value-added, urbanization, industrial growth and carbon dioxide emissions $\left(\mathrm{CO}_{2}\right)$ on economic growth of Pakistan. The empirical findings of dynamic ARDL simulation model reported that electricity consumption and industrial value-added improve economic growth, whereas electricity prices showed insignificant result in improving economic growth. Furthermore, $\mathrm{CO}_{2}$ emissions and urbanization effect economic growth positively only in short-run.

Focusing on the factors impacting the carbon neutrality target for 37 OECD economies over the period 1970-2017, Iqbal et al. (2021) incorporated export diversification, environment-related technological innovation, and fiscal decentralization in the study. The empirical analysis of updated cointegration technique and augmented group (AMG) reported that fiscal decentralization, export diversification, and GDP growth increase while environment-related technological innovation and renewable energy consumption alleviate carbon emissions in selected OECD countries.

Similarly, Tufail et al. (2021) explored empirically the linkage of $\mathrm{CO}_{2}$ with fiscal decentralization, total natural resource rent, GDP and institutional quality for the seven highly fiscal decentralized economies from OECD countries over the period 1990 to 2018. The findings of cross-sectional autoregressive distributed lag order model confirm that fiscal decentralization, institutional quality and the joint term of fiscal decentralization and total natural resource rent mitigate $\mathrm{CO}_{2}$ emissions, whereas, individually, the total natural resource rent along with GDP cause $\mathrm{CO}_{2}$ emissions to rise in both short- and long-run in the selected OECD economies.

Exploring the data set for the central and eastern Europe, Radulescu et al. (2018) employed co-integration and OLS panel estimation technique to explore the important drivers of the Europe 2020 strategy affecting economic performance and economic competitiveness. The findings revealed that tertiary level of education is a crucial factor in achieving economic performance and economic competitiveness. Moreover, the school dropout ratio, employment rate, and renewable energy consumption are also important factors in achieving economic performance and competitiveness in central and eastern European countries. 
More recently, Khan et al. (2021) examined the possible impact of fiscal decentralization on carbon emissions between 1990 and 2018 in a balanced panel of seven OECD economies (Australia, Austria, Belgium, Canada, Germany, Spain and Switzerland) by employing CS-ARDL and Westerlund cointegration techniques. The empirical findings revealed that fiscal decentralization enhanced environmental quality. Additionally, the connection between fiscal decentralization and environmental quality is assisted by better quality of institutions and development of human capital.

Regarding the carbon neutrality agenda 2060 of China, Liu et al. (2021) utilized household consumption-induced carbon emissions data for Chinese provinces between 1995 and 2017. The results of polled mean group, the common correlated effects mean group and cross-sectional augmented autoregressive distributed lag estimators showed that household consumption and financial development are responsible for greater carbon emissions while technological innovations and renewable energy consumption were established to limit the carbon emissions.

Concluding from literary studies on carbon emissions, consumption-based emission index is a new and more suitable measurement approach relatively to territorial-based carbon emissions as the number of studies have considered it previously but gained more attention recently in climate change and environment pollution discussions (Ali et al. 2020; Hasanov et al. 2018; Karakaya et al. 2019; Knight and Schor 2014; Liddle 2018).

For instance, Liddle (2018) studied a panel of developing and developed economies for both consumption and territorial-based emissions while Knight and Schor (2014) considered oil-exporting nations using different methodology. More recently, Safi et al. (2021) incorporated financial instability to inquire its effect on consumption-based carbon emissions on E-7 (seven emerging economies). Hasanov et al. (2018) considered oil-exporting economies to examine disaggregated impact of exports and imports on consumption as well as territorial-based carbon emissions. Exploring the provincial data of China, Chen et al. (2018) examined the impact of environmental regulations, shadow economy and corruption on environmental quality. While Zhou et al. (2020) found that the anti-corruption by the Chinese government significantly lessened the sir pollution in city-level data of China, Hasanov et al. (2021) investigated the effect of technological innovations, renewable energy consumption and magnitude of exports in BRICS economies.

The present empirical study has several unique aspects, which, to the best of our knowledge, have not investigated in any of the previous study; (i) The current study examines the impact of Economic risk, Political risk, Financial risk and Composite risk on consumption-based carbon emissions. (ii) This study considers an unexplored panel data set of Regional Comprehensive Economic Partnership (RCEP) economies. (iii) In the presence of the aforementioned characteristics, this study also examined the role of renewable energy supply in mitigating consumption-based carbon emissions. (iv) Also, this is the first study to consider consumption-based carbon emissions in RCEP selected economies. (v) The methodologies and estimations strategies employed for empirical analysis are robust and authentic: CIPS Unit root test, Cross-sectional dependence test, Slope heterogeneity, CS-ARDL mean group, Westerlund cointegration (2007), and Dumitrescu-Hurlin panel causality test (2012).

\section{Methods and estimations strategies}

\section{Theoretical framework}

Globally, consumption and production-based carbon emissions are different sides of the same coin; total global consumption-based carbon emissions must be equal to total global production-based carbon emissions. However, based on individual country point of view, these two measures vary significantly subject to the nature and magnitude of the international trade practices. This measure is evaluated as emissions from imports plus consumption demand from the government and household domestically and excluding exports (Liddle 2018). The territorial-based carbon emissions statistics are falling in some economies but meanwhile their consumption-based carbon emissions are on rise; for instance, Singapore and Philippine (Peters et al. 2012). Consumption-based carbon emissions approach not only consider global production chain but also reports the origin of emissions and distinguish between emissions producer and emissions consumer economies (Peters et al. 2011). Figure 3 depicts trade-adjusted and territorial-based carbon emissions of RCEP economies for the last six years. Data visualization in Fig. 3 reports that territorial carbon emissions are falling but meanwhile trade-adjusted carbon emissions are on rise in RCEP economies specifically in 2016, 2017 and 2018. Furthermore, RCEP economies are responsible for almost one third of trade adjusted carbon emissions globally in 2018. Figure 4 highlights that out of 36,420 metric tons of trade-adjusted carbon emissions, RCEP economies were responsible for 12,977 metric tons of carbon emissions in 2018.

The role of trade has been widely explored in literary studies considering trade-carbon emissions nexus by Al-mulali and Sheau-Ting (2014); Hossain (2011); Shahbaz et al. (2017). However, they only consider territorial-based carbon emissions and do not take into account consumption-based carbon emissions. Ali et al. (2020); Hasanov et al. (2021); Hasanov et al., (2018); Khan et al. (2020); Safi et al. (2021) further improved the former analysis by adding into literature the effect of trade on consumption-based carbon emissions by considering disaggregated exports and imports. Based on 
Fig. 3 Production vs consumption-based emissions in RCEP economies since 2015

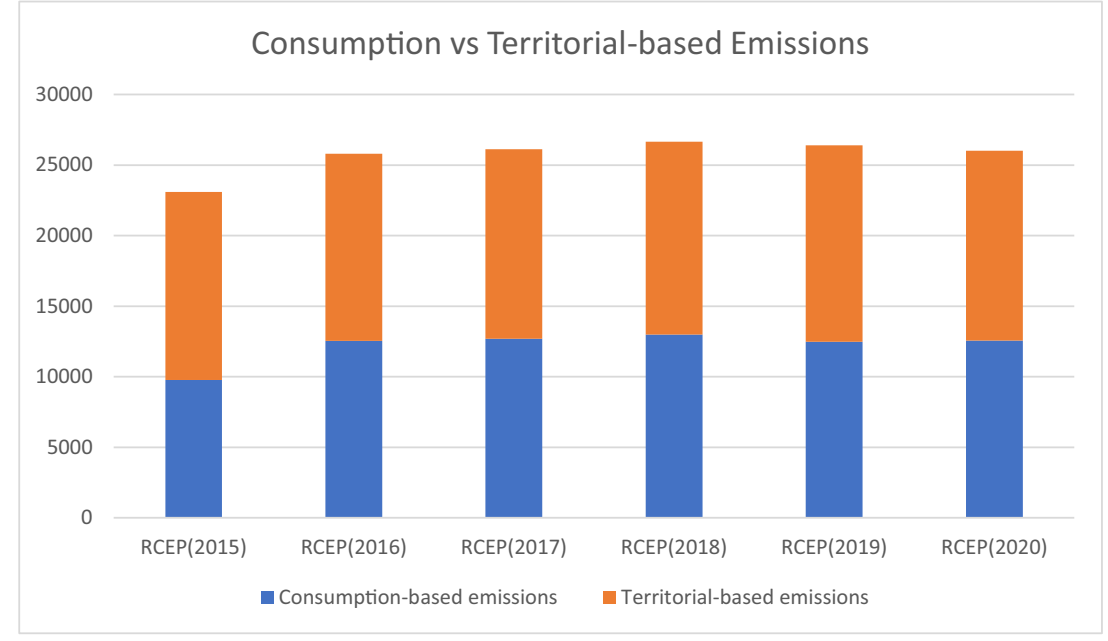

consumption-based carbon emissions approach, it is expected that exporting economy shall show fall while importing economy shall show rise in carbon emissions (Al-mulali and Sheau-Ting 2014; Chen et al. 2018; Hasanov et al. 2018; Knight and Schor 2014). This effect of exports and imports on carbon emissions could be justified by the fact that as exports transfer the emissions of the item from exporting economy (producer economy) to the importing economy (consumer economy) where it is finally consumed or operated. Thus, this study utilizes exports and imports separately, to capture the component-based effect of trade on $\mathrm{CCO}_{2}$, which is consistent with previously mentioned studies. Considering consumption-based carbon emissions approach, based on previously mentioned results, we expect exports negatively while imports positively affect consumption-based carbon emissions. The data illustration in Fig. 5 depicts exports and imports of carbon emitting goods of RCEP economies in 2018 in billion US dollars. Fig. 5 reveals that except Thailand, the worth of exports in selected RCEP economies is higher than the worth of imports in billion US dollars in the year 2018. The Top exports and imports of selected RCEP economies in the year 2018 are reported in Table 2 in billions of US dollars. Most of RCEP economies top exports are either integrated circuits or broadcasting equipment while the imports consist of either crude or refined petroleum.

\section{Consumption-based CO2 Emissions (Mtco2)} (2018)

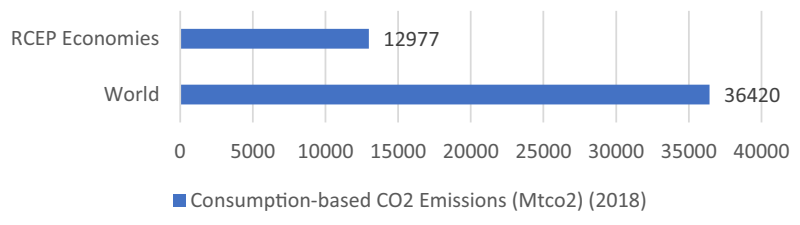

Fig. 4 Consumption-based $\mathrm{CO}_{2}$ emissions of RCEP economies
The Gross domestic product (GDP) reports many information regarding components of an economy, such as investment, government expenditures and net exports. A significant share of GDP is cover by domestic consumption, implies that more domestic consumption result in more $\mathrm{CCO}_{2}$ emissions. However, as the selected RCEP countries are high-income economies, it is reasonable to assume that these economies have imported emissions through trade and consumption activities (Lau et al. 2014; Seker et al. 2015; Seker et al. 2015; Hasanov et al. 2018; Lau et al. 2014).

Renewable energy consumption or supply that originates from cleaner energy sources is mostly associated with zero or less carbon emissions (Ali et al. 2020; Bekun et al. 2019; Destek and Aslan 2020; Liu et al. 2021; Saint Akadiri et al. 2019; Sharif et al. 2019; Ulucak and Khan 2020). Generally, the supply or consumption of energy generated from cleaner or renewable sources (hydro, geothermal, solar, wind, combustible renewables, renewable waste) play a vital role in cleaner production and sustaining environmental quality as compared to non-renewable sources (fossil fuels, etc.). Hence, we expect a mitigating effect of renewable energy supply on consumption-based carbon emissions. Figure 6 portrays the share of renewable energy supply percent of total final energy supply in RCEP economies. It is obvious that the share of renewable energy supply in New Zealand, Indonesia, Philippines, Thailand and Vietnam is higher than other RCEP economies in the year 2018 and 2019.

The present study considers four different risk ratings of an economy in disaggregated form: Economic risk, Political risk, Financial risk along Composite risk that could possibly affect $\mathrm{CCO}_{2}$ emissions. Each risk comprises of different components reported in Table 3. Economic risk determines economic strengths and weaknesses of an economy. The higher the total risk point, the lower the risk, and the lower the total risk points, the higher the risk in every case (Economic, Political, Financial and Composite risk). 
Table 2 Top exports and imports of RCEP economies in 2018

\begin{tabular}{lll}
\hline Country & Top exports & Top imports \\
\hline Australia & Coal Briquettes $(\$ 57.2 \mathrm{~B})$ & Refined Petroleum $(\$ 18.5 \mathrm{~B})$ \\
Japan & Vehicles $(\$ 103 \mathrm{~B})$ & Crude petroleum $(\$ 72.3 \mathrm{~B})$ \\
Korea, Rep. & Integrated Circuits $(\$ 113 \mathrm{~B})$ & Crude petroleum $(\$ 74.8 \mathrm{~B})$ \\
New Zealand & Concentrated Milk $(\$ 5.08 \mathrm{~B})$ & Vehicles $(\$ 3.28 \mathrm{~B})$ \\
China & Broadcasting Equipment $(\$ 224 \mathrm{~B})$ & Crude Petroleum $(\$ 208 \mathrm{~B})$ \\
Indonesia & Coal Briquettes $(\$ 22.1 \mathrm{~B})$ & Refined Petroleum $(\$ 15.1 \mathrm{~B})$ \\
Malaysia & Integrated Circuits $(\$ 55.5 \mathrm{~B})$ & Integrated Circuits $(\$ 29.6 \mathrm{~B})$ \\
Philippines & Integrated Circuits $(\$ 30.7 \mathrm{~B})$ & Integrated Circuits $(\$ 20.1 \mathrm{~B})$ \\
Singapore & Integrated Circuits $(\$ 61 \mathrm{~B})$ & Refined Petroleum $(\$ 48 \mathrm{~B})$ \\
Thailand & Office Machines Parts $(\$ 18.6 \mathrm{~B})$ & Crude Petroleum $(\$ 23.7 \mathrm{~B})$ \\
Vietnam & Broad casting Equipment $(\$ 42.8 \mathrm{~B})$ & Integrated Circuits $(\$ 23 \mathrm{~B})$ \\
\hline
\end{tabular}

Note: Authors own calculation based on data gleaned from OEC world database
With the expansion in economic growth, economic activities rise that generate opportunities and improve income level. During such expansion, economies consume more energy in order to fuel their domestic industry during transitional stage. At the same time, environmental economists state that such drastic expansions lead to a rise in carbon emissions and further deteriorate environmental quality, also explained by EKC hypothesis in first stage; economic growth or rise in income is associated with environmental pollution (Al-mulali and Sheau-Ting 2014; Al Mamun et al. 2014; Ali et al. 2020; Bekun et al. 2019). Therefore, we expect that economic risk is positively associated with consumption-based carbon emissions.

The political risk index assesses the stability of political system of an economy that consists of 12 components. The higher political risk implies weak or unstable government, poorly or less education rate, poverty, inequities in access to resources, risky investment background along with more corrupt officials and weak institutions. Generally, developing countries with high political risk confront multiple hardships. For instance, more corrupt officials could weaken environmental regulations that lead to illegal production and add in to more emissions (Chen et al. 2018). While an anti-corruption campaign is helpful to limit corruption and consequently mitigate environmental pollution (Zhou et al. 2020). Similarly, strong institutions play a crucial role in protecting environment quality by imposing strict regulations and penalties for any activity involving illegal emissions (Ali et al. 2019; Khan et al. 2021). Hence, we expect that political strength of an economy play a vital role in limiting consumption-based carbon dioxide emissions.

The financial risk measures a country's capacity to finance its government activities including official, commercial, and trade debt obligations. Conclusively, the lower the financial risk of an economy, the more productive the economy is, and is capable of paying back its debt. Furthermore, countries with stable exchange rates attract foreign capital due to less financial risk. For example, Safi et al. (2021) found that financial instability, exports and technological innovations have negative effect on consumption-based carbon emissions, which implies that economic activities in financially instable economies do not operate efficiently due to poor productive
Fig. 5 Export and imports of carbon emitting goods in billions of US dollars in RCEP economies in 2018

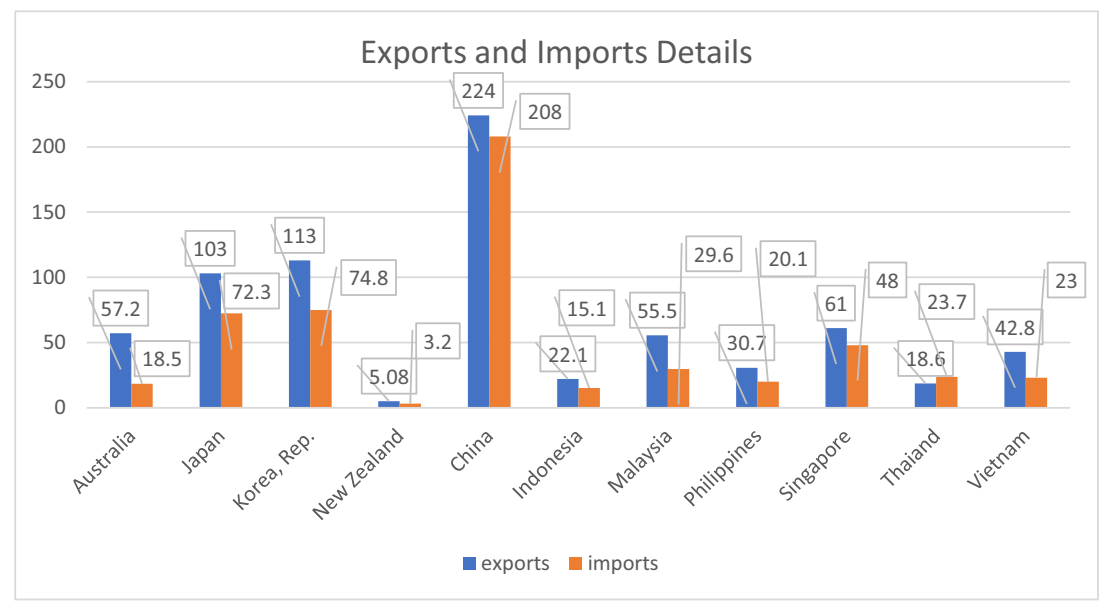


Fig. 6 Renewable energy supply percent of total final energy supply in selected RCEP economies in last two years

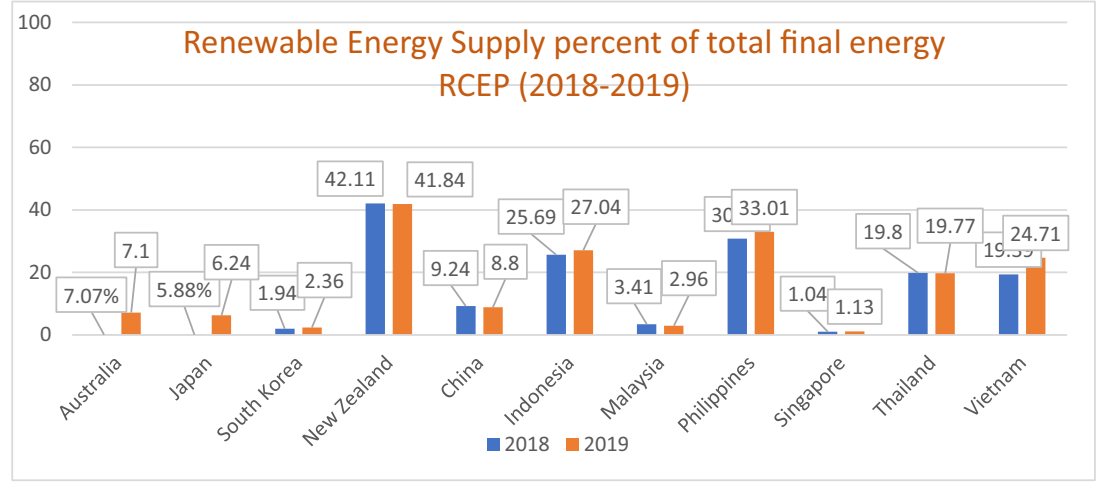

capabilities, lack of financing government activities, high foreign debt and unstable exchange rate, etc. A study by Zhang (2011) reports that less financial risk (financial development) acts as a major driver for increase in carbon emissions in China. Hence, we expect that that less financial risk triggers consumption-based carbon emissions.

The aggregate of political, financial and economic risk, called composite risk is calculated by International Country Risk Guide (ICRG) using the formula "A". The political risk rating presents $50 \%$ of the composite rating while economic and financial risk ratings each account for $25 \%$. Hence, it would be interesting to test empirically the impact of aggregate of prior mentioned three risks on consumption-based carbon dioxide emissions. If the expected sign for ECORISK, FINRISK and POLRISK in Table 4 holds true, then we expect an increase in consumption-based carbon dioxide emissions with improvement in composite risk rating ${ }^{1}$.

\section{COMRISKx, $i$}

$$
=0.5(\text { POLRISKx }, i+\text { FINRISKx }, i+\text { ECORISKx }, i)(\mathrm{A})
$$

The present study inquires whether a change in $\mathrm{CCO}_{2}$ emissions is associated with a change in political, economic, financial and composite risk of selected RCEP economies. Moreover, considering consumption-based approach for carbon dioxide emissions measurement, it will be interesting to explore the empirical linkage between exports, imports and renewable energy supply.

\section{Data sources and variables}

The current study investigates consumption-based carbon emissions $\left(\mathrm{CCO}_{2}\right)$ its possible linkage with Economic (ECORISK), Financial (FINRISK), Political (POLRISK) and Composite Risk (COMRISK) along with role of

\footnotetext{
${ }^{1}$ The formula is designed by International Country Risk Guide (ICRG) for calculating aggregate risk rating.
}

renewable energy (RES), economic growth (GDPP) and impact of disaggregated exports (EX) and imports (IM) in selected RCEP economies between 1990 and 2020. The dependent variable, $\mathrm{CCO}_{2}$ emissions, measure in metric tons, all the four risk ratings are drawn from International Country Risk Guide dataset, Renewable energy supply (RES) measured in percentage is gleaned from OECD website, while gross domestic product per-capita, exports and imports are measured in constant 2010 US\$ and gathered from World Development Indicators. Table 4 represents a list of variables, sources, measurement units, expected sign and notations in details.

\section{Model specifications}

The fundamental model of the study considers the disaggregation of international trade into exports and imports to capture the influence of sub-components of trade on $\mathrm{CCO}_{2}$ emissions, the technique in line with recently published studies (Ali et al. 2020; Hasanov et al. 2021; Khan et al. 2020; Liddle 2018; Safi et al. 2021). Top imports of RCEP economies include either crude or refined petroleum reported in Table 2, which is a possible explanation to treating exports and imports individually due to the fact these imports may significantly cause $\mathrm{CCO}_{2}$ emissions. The following Model 1 represents the fundamental model of this study. Furthermore, four different models are designed by incorporating renewable energy supply (RES), Financial risk (FINRISK), Economic risk (ECORISK), Political risk (POLRISK) and Composite risk (COMRISK) in Model 1. In order to capture a clear impact of each independent variable on the consumption-based carbon emissions, this study structured five different models for empirical analysis given as:

Model 1: Fundamental model

$$
C C O_{2 i, t}=f\left(E X_{i, t}, I M_{i, t}, G D P P_{i, t}\right)
$$


Table 3 Sub-components of risks

\begin{tabular}{llll}
\hline Risk & Political risk & Economic risk & Financial risk \\
\hline $\begin{array}{c}\text { Risk } \\
\text { compo- } \\
\text { nents }\end{array}$ & $\begin{array}{l}\text { Government Stability } \\
\text { Socioeconomic } \\
\text { conditions } \\
\text { Investment profile }\end{array}$ & $\begin{array}{l}\text { GDP per-capita } \\
\text { Real GDP growth }\end{array}$ & $\begin{array}{c}\text { Foreign debt \% of GDP } \\
\text { Foreign debt as \% of export of goods and } \\
\text { services } \\
\text { Current account as \% of exports of goods } \\
\text { \& services }\end{array}$ \\
& Internal conflict & $\begin{array}{c}\text { Budget Balance } \% \text { of } \\
\text { GDP }\end{array}$ & $\begin{array}{c}\text { Net international liquidity as months of } \\
\text { import cover }\end{array}$ \\
& External conflict & Current account $\%$ of & Exchange rate stability \\
& GDP & \\
Corruption & & \\
Military in politics & & \\
Religious tensions & & \\
Law \& order & & \\
Ethnic Tensions & & \\
Democratic & & \\
Accountability & & \\
Bureaucracy quality & & \\
\hline
\end{tabular}

Source: International Country Risk Guide (ICRG)

Model 2: Incorporation of FINRISK \& RES

$C C O_{2 i, t}=f\left(E X_{i, t}, I_{i, t}, G D P P_{i, t}, E_{C O R I S K}, t, R E S_{i, t}\right)$

$C C O_{2 i, t}=f\left(E X_{i, t}\right.$ IM $_{i, t}$, GDPP $_{i, t}$, FINRISK $_{i, t}$, RES $\left._{i, t}\right)$

Model 4: Incorporation of POLRISK \& RES

Model 3: Incorporation of ECORISK \& RES

$C C O_{2 i, t}=f\left(E X_{i, t}, I_{i, t}, \operatorname{GDPP}_{i, t}, \operatorname{POLRISK}_{i, t}, \operatorname{RES}_{i, t}\right)$

Table 4 Variables and data sources

\begin{tabular}{|c|c|c|c|}
\hline Variables & Definition and measurement units & Data source & $\begin{array}{l}\text { Expected } \\
\text { sign }\end{array}$ \\
\hline $\mathrm{CCO}_{2}$ & $\begin{array}{l}\text { Consumption-based carbon dioxide emissions } \\
\text { measured in Metric ton of carbon dioxide }\end{array}$ & $\begin{array}{l}\text { Peters et al. (2012) and } \\
\text { Peters et al. (2011) }\end{array}$ & -- \\
\hline EX & Export of goods \& services (constant 2010 US\$) & $\begin{array}{l}\text { World Development } \\
\text { Indicators }\end{array}$ & Negative \\
\hline $\mathrm{IM}$ & Import of goods \& services (constant 2010 US\$) & $\begin{array}{l}\text { World Development } \\
\text { Indicators }\end{array}$ & Positive \\
\hline GDPP & $\begin{array}{l}\text { Gross domestic product per capita (constant } 2010 \text { US } \\
\text { \$) }\end{array}$ & $\begin{array}{l}\text { World Development } \\
\text { Indicators }\end{array}$ & Positive \\
\hline \multirow[t]{2}{*}{ RES } & \multirow[t]{2}{*}{ Renewable energy supply, \% total energy supply } & https://stats.oecd.org & \multirow[t]{2}{*}{ Negative } \\
\hline & & $\begin{array}{l}\text { Data set: Green Growth } \\
\text { Indicators }\end{array}$ & \\
\hline FINRISK & Financial risk & $\begin{array}{l}\text { International country risk } \\
\text { guide (ICRG) }\end{array}$ & Positive \\
\hline POLRISK & Political risk & $\begin{array}{l}\text { International country risk } \\
\text { guide (ICRG }\end{array}$ & Negative \\
\hline ECORISK & Economic risk & $\begin{array}{l}\text { International country risk } \\
\text { guide (ICRG }\end{array}$ & Positive \\
\hline COMRISK & Composite risk & $\begin{array}{l}\text { International country risk } \\
\text { guide (ICRG }\end{array}$ & -- \\
\hline
\end{tabular}


Model 5: Incorporation of COMRISK \& RES

$$
C C O_{2 i, t}=f\left(E X_{i, t}, I_{i, t}, \operatorname{GDPP}_{i, t}, \operatorname{COMRISK}_{i, t}, \operatorname{RES}_{i, t}\right)
$$

Where $\mathrm{CCO}_{2}$ denotes that consumption-based carbon dioxide emissions is dependent variable followed by exports (EX), imports (IM), gross domestic product per capita (GDPP), renewable energy supply (RES), financial risk (FINRISK), economic risk (ECORISK), political risk (POLRISK), composite risk (COMRISK) as independent variables. Except the risk ratings and renewable energy supply, all variables are transformed into a logarithmic specification. The log transformation made it easy to explain coefficients and estimates and to have a constant variance. The subscripts $i$ and $t$ depicts time (1990-2020) and cross-sectional dimensions of 11 RCEP economies, respectively.

While dealing with cross-country data analysis, the issue of cross-section dependency, endogeneity and heterogeneity is linked. In order to resolve these issues, several tests are applied. Pesaran and Yamagata (2008) test for slope heterogeneity is applied for each model followed by cross-section dependence tests. The study utilized Pesaran (2007) panel unit root test with cross-sectional and first difference mean (CIPS) due to its power of dealing with cross-section dependence and heterogeneity problems. Next, the Westerlund (2007) cointegration technique was applied for each model. The CS-ARDL approach is employed for estimating long-run coefficients. Both, Westerlund (2007) and CS-ARDL approaches are robust to cross-section dependency and slope heterogeneity. The problems of cross-section dependence, heterogeneity and endogeneity are well addressed in the models.

\section{Econometric methods}

\section{Cross-section dependence and slope heterogeneity}

The study empirically investigates the impact of economic risk (ECORISK), financial risk (FINRISK), political risk (POLRISK) and composite risk (COMRISK) along with exports (EX), imports (IM) and renewable energy supply (RES) on consumption-based carbon dioxide emissions in selected RCEP economies. Due to cross-sectional dependency (CSD) among countries in the study, the empirical results may provide deceptive results. Therefore, this study employs second generation econometric technique which considers cross-section dependency. The widely known Pesaran (2004) CD-test is employed in this study for cross-sectional dependency and the equation is given below:
$C D_{\text {pesaran (2004), } i}=\sqrt{\frac{2 \mathrm{~T}}{N(N-1)}}\left(\sum_{i=1}^{N-1} \sum_{k=i+k}^{N} \widehat{\tau} i k\right)$

The Pesaran (2004) test for cross-section dependence assumes zero mean constant and variance. The term " $\widehat{\tau} i k$ " represent pairwise correlation in Equation 6.

As previously mentioned, panel data estimations commonly face slope heterogeneity issue, which may lead to specious results. Hence, the present study overcome this issue by employing Pesaran and Yamagata (2008) slope heterogeneity test which consider CSD in the data and further improves the robustness of the results. In addition, Pesaran and Yamagata (2008) test provides consistent results when $\mathrm{N}<\mathrm{T}$. The Pesaran and Yamagata (2008) equations are as follow:

$\widetilde{\Delta}_{S H}=(N)^{\frac{1}{2}}(2 k)^{-\frac{1}{2}}\left(\frac{1}{N} \widetilde{S}-k\right)$

$\widetilde{\Delta}_{A S H}=(N)^{\frac{1}{2}}\left(\frac{2 k(T-k-1)}{T+1}\right)^{-\frac{1}{2}}\left(\frac{1}{N} \widetilde{S}-2 k\right)$

\section{Panel unit root analysis}

Taking into consideration the issue of CSD and heterogeneity, this investigation applies cross-sectional augmented IPS (CIPS) panel unit root test. CIPS test is useful due to its properties of dealing with cross-sectionally dependent variables and provides robust results in case of slope heterogeneity issue (Pesaran 2007). The equation form of CIPS is as follow:

$C I \widehat{P S}=N^{-1} \sum_{i=0}^{n} C D F_{i}$

\section{Westerlund cointegration approach}

In order to explore the impact of exports (EX), imports (IM), renewable energy supply (RES) along with four different risk ratings (economic risk (ECORISK), political risk (POLRISK), financial risk (FINRISK) and composite risk (COMRISK)) on consumption-based carbon emissions $\left(\mathrm{CCO}_{2}\right)$ in selected RCEP economies, this investigation involves Westerlund (2007) technique for cointegration. In the presence of CSD and slope heterogeneity, other panel cointegration tests may provide deceptive results. Furthermore, Westerlund (2007) cointegration test for a small sample size provide valid results (Bhattacharya et al. 2018). The test inspects cointegration in whole group as well as across individual cross-sections. The 
group test statistics $\left(\boldsymbol{G}_{\boldsymbol{t}}\right.$ and $\left.\boldsymbol{G}_{\boldsymbol{a}}\right)$ and cross-sections test statistics $\left(\boldsymbol{P}_{\boldsymbol{t}}\right.$ and $\left.\boldsymbol{P}_{\boldsymbol{a}}\right)$ are as follow:

$\boldsymbol{G}_{\boldsymbol{t}}=\frac{1}{N} \sum_{i-1}^{N} \frac{\alpha_{i}}{S E\left(\alpha_{i}\right)}$

$\boldsymbol{G}_{\boldsymbol{a}}=\frac{1}{N} \sum_{i-1}^{N} \frac{T \alpha_{i}}{\alpha_{i}(1)}$

$\boldsymbol{P}_{\boldsymbol{t}}=\frac{\alpha}{S E(\alpha)}$

$\boldsymbol{P}_{\boldsymbol{a}}=T \alpha$

Where the error correction is denoted by $\alpha$, can be calculated by incorporating $T$ and $P_{a}$ values in Equation (13).

\section{Long and short-run results estimation}

To estimate the long and short-run coefficients for model 1-5, this study employed second-generation cross-section augmented autoregressive distributed lags model (CS-ARDL) (Chudik and Pesaran 2015). This approach is preferred due to its efficient results and superiority over other conventional estimation techniques in many ways; First, unlike mean group (MG) and polled-mean group (PMG) estimation approaches, CS-ARDL is equipped to tackle the issues of cross-section dependency (CSD) and slope heterogeneity (SH). Secondly, this approach is applicable even for a mixed order of integration or handling non-stationarity problem (Chudik et al. 2017). Third, it effectively handles the problem of endogeneity. The general equation form of CS-ARDL is as following:

$$
\begin{aligned}
\Delta C C O_{2}= & \vartheta_{i}+\sum_{I=1}^{p} \vartheta_{i I} \Delta C C O_{2, i, t}+\sum_{I=0}^{p} \vartheta_{i I} \bar{Z}_{s, i, t-1} \\
& +\sum_{I=0}^{1} \vartheta_{i I} \overline{A C}_{i, t-1}+\varepsilon_{i, t}
\end{aligned}
$$

Where $\overline{A C}$ represents cross-section averages and all independent variables are denoted by $\mathrm{Z}$.

\section{Dumitrescu and Hurlin panel causality}

Moreover, to examine the causal link among the observed variables, this study employs pairwise (Dumitrescu and Hurlin 2012) panel causality test. The test provides effective results when the residual terms are cross-sectionally dependent. The test is applicable when time period is relatively large as compared to cross-sections $(T>N)$, which best fits our panel data. The equation form of the test is given as:

$Z_{i, t}=\alpha_{i}+\sum_{j=1}^{p} \gamma_{t}^{j} Z_{i, t-j}+\sum_{j}^{p} \gamma_{t}^{j} T_{i, t-j}$

Where $\gamma_{t}^{j}$ denotes autoregressive parameters while lag length is represented by $\mathrm{j}$.

\section{Results and discussions}

This section shows the results of the econometric estimations and tests applied in this paper. Prior to other estimations, it is important to evaluate descriptive statistics, cross-sectional dependency, slope heterogeneity and stationarity. Descriptive statistics of observed variables are reported in Table 5. Panel A of Table 6 presents the results of cross-sectional dependency of variables while Panel B presents slope heterogeneity in all models, respectively. The results of CD test verify the presence of CSD, as the test values strongly reject the null hypothesis of cross-sectional independence of all variables at $1 \%$ except RES at $5 \%$ of significance. Further, Panel B of Table 6 presents the Pesaran and Yamagata (2008) test results of slope heterogeneity. The significant values of delta and adjusted delta support the rejection of null hypothesis of homogenous slope coefficients which implies that all models suffer from problem of slope heterogeneity. A possible explanation for the slope heterogeneity may be due to the diverse economic structure of RCEP economies. Furthermore, it also implies the interconnectedness of RCEP economies; a shock in one country has repercussions for other countries.

\section{Unit root test}

After confirming the slope heterogeneity in models and cross-sectional dependency of variables, the empirical investigation is followed by second generation CIPS unit-root test to check order of integration. Table 7 reports the outcomes of CIPS test at level and at first difference. The results confirmed that all variables except economic risk (ECORISK) exhibit the same integration order I (1).

\section{Westerlund cointegration}

Considering the issue of heterogeneity and CSD across cross-sections, the present study applies Westerlund (2007) panel cointegration technique to all five models. The results of Westerlund (2007) cointegration tests are reported in Table 8 . The significance group and panel statistics confirms 
Table 5 Descriptive statistics

\begin{tabular}{llllllllll}
\hline & $\mathrm{CCO}_{2}$ & EX & IM & GDPP & ECORISK & FINRISK & POLRISK & COMRISK & RES \\
\hline Mean & 790.88 & 53.163 & 49.816 & 18626.4 & 36.032 & 38.423 & 71.110 & 72.618 & 18.831 \\
Median & 214.63 & 32.590 & 31.933 & 8254.5 & 37.333 & 39.583 & 71.000 & 73.196 & 11.665 \\
Maximum & 8959.9 & 228.99 & 208.33 & 59073.4 & 48.541 & 49.041 & 90.916 & 90.750 & 73.176 \\
Minimum & 22.944 & 8.9717 & 6.9360 & 433.2 & 13.336 & 5.7500 & 36.916 & 34.126 & 0.2824 \\
Std. Dev. & 1668.2 & 49.101 & 42.933 & 18489.2 & 6.0096 & 6.7610 & 11.624 & 9.535 & 17.693 \\
Obs & 341 & 341 & 341 & 341 & 341 & 341 & 341 & 341 \\
\hline
\end{tabular}

the cointegrating relationship among groups and across all cross-sections respectively.

\section{Long and short-run estimations}

The confirmation of cointegration relationship among variables from Westerlund (2007) panel cointegration tests encourages the empirical analysis to scrutinize for long and short-run relationship among variables. The cointegrated variable results also verify the validity of estimated coefficients and can be used for forecasting analysis. Furthermore, the equilibrium error correction term should be present among the variables. For this purpose, we employed second generation cross-sectional augmented autoregressive distributed lags model for all five models, which handle the issues of cross-sectional dependency, slope heterogeneity and

Table 6 Cross sectional dependence and slope heterogeneity analysis

\begin{tabular}{lll}
\hline Variables & \multicolumn{1}{l}{ Test statistics } & P-values \\
\hline Panel A: Cross-sectional dependence test & \\
$\mathrm{CCO}_{2}$ & $29.384 * * *$ & 0.00 \\
$\mathrm{EX}$ & $10.982^{* * *}$ & 0.00 \\
$\mathrm{IM}$ & $9.591 * * *$ & 0.00 \\
GDPP & $40.016^{* * *}$ & 0.00 \\
RES & $2.174 * *$ & 0.30 \\
ECORISK & $22.009 * * *$ & 0.00 \\
FINRISK & $3.661 * * *$ & 0.00 \\
POLRISK & $12.743 * * *$ & 0.00 \\
COMRISK & $15.393 * * *$ & 0.00 \\
Panel B: Slope heterogeneity & \\
Models & Delta_tilde & Adjusted Delta tilde \\
Model-1 & $21.695 * * *$ & $23.690 * * *$ \\
Model-2 & $17.002 * * *$ & $19.322 * * *$ \\
Model-3 & $18.394 * * *$ & $20.905 * * *$ \\
Model-4 & $17.701 * * *$ & $20.117 * * *$ \\
Model-5 & $17.764 * * *$ & $20.189 * * *$ \\
\end{tabular}

Note: The level of significance is determined by 1,5 , and $10 \%$ indicated through $* * *, * *$ and $*$ respectively, while () contains $\mathrm{P}$-values non-stationarity. Table 9 reports the estimated results based on CS-ARDL method.

The estimated results in Table 9 demonstrate that exports, imports, GDP per-capita, renewable energy supply, financial risk, economic risk, political risk and composite risk are relatively important elements describing $\mathrm{CCO}_{2}$ emissions. The hypothesized linkage of risk ratings (economic risk, financial risk, composite risk, political risk) and other variables (exports, imports, GDP per-capita, and renewable energy supply) with $\mathrm{CCO}_{2}$ is validated by the lingering value of error correction term. The negative coefficients of exports (EX), renewable energy supply (RES) and political risk (POLRISK) indicates that a growth in these factors is associated with decrease in $\mathrm{CCO}_{2}$ emissions significantly in RCEP economies. Conversely, an increase in imports (IM), GDP per-capita (GDPP), financial risk (FINRISK), economic risk (ECORISK), and composite risk (COMRISK) significantly rise $\mathrm{CCO}_{2}$ emissions (except for imports in model 1 and exports in model 4 and model 5). Particularly, the long-run elasticities estimate of EX, IM, GDPP, FINRISK, RES, ECORISK, POLRISK, and COMRISK are $-0.210 \%$, $0.206 \%, 0.934 \%, 0.240 \%,-0.026 \%, 0.167 \%,-0.177 \%$ and $0.138 \%$, respectively. The higher the risk rating value in every

Table 7 Results of CIPS unit root

\begin{tabular}{llll}
\hline Variables & $\begin{array}{l}\text { Level } \\
\text { Trend and constant }\end{array}$ & $\begin{array}{l}\text { First difference } \\
\text { Trend and constant }\end{array}$ & $\begin{array}{l}\text { Order of } \\
\text { integration }\end{array}$ \\
\hline $\mathrm{CCO}_{2}$ & -2.351 & $-5.204 * * *$ & $\mathrm{I}(1)$ \\
$\mathrm{EX}$ & -2.423 & $-4.817 * * *$ & $\mathrm{I}(1)$ \\
$\mathrm{IM}$ & -2.567 & $-4.894 * * *$ & $\mathrm{I}(1)$ \\
GDPP & -1.117 & $-3.713 * * *$ & $\mathrm{I}(1)$ \\
RES & -2.137 & $-5.612 * * *$ & $\mathrm{I}(1)$ \\
ECORISK & $-3.464 * * *$ & - & \\
FINRISK & -2.609 & $-4.922^{* * *}$ & $\mathrm{I}(1)$ \\
POLRISK & -2.332 & $-4.703 * * *$ & $\mathrm{I}(1)$ \\
COMRISK & -2.664 & $-5.054 * * *$ & $\mathrm{I}(1)$ \\
\hline
\end{tabular}

Note: Asterisks denote a significance level of $10 \%(*), 5 \%(* *)$ and $1 \%$ $(* * *)$ 
Table 8 Westerlund Cointegration test

\begin{tabular}{|c|c|c|c|c|c|}
\hline Statistics & Model-1 & Model-2 & Model-3 & Model-4 & Model-5 \\
\hline$G^{t}$ & $-7.218 * * *$ & $-6.487 * * *$ & $-7.33 * * *$ & $-7.12 * * *$ & $-6.73 * * *$ \\
\hline$G^{a}$ & $-37.582 * * *$ & $-29.621 * * *$ & $-31.12 * * *$ & $-31.82 * * *$ & $-29.45 * * *$ \\
\hline$P^{t}$ & $-24.276^{* * *}$ & $-19.541 * * *$ & $-21.97 * * *$ & $-21.84 * * *$ & $-22.06 * * *$ \\
\hline$P^{a}$ & $-42.374 * * *$ & $-31.971 * * *$ & $-35.175 * * *$ & $-34.16^{* * *}$ & $-33.76^{* * *}$ \\
\hline
\end{tabular}

Note: Asterisks denote a significance level of $10 \%(*), 5 \%(* *)$ and $1 \%(* * *)$

Table 9 CS-ARDL

\begin{tabular}{|c|c|c|c|c|c|}
\hline \multicolumn{6}{|c|}{ Dependent Variable: $\mathrm{CCO}_{2}$ emtco2 } \\
\hline Variables & Model-1 & Model-2 & Model-3 & Model-4 & Model-5 \\
\hline \multicolumn{6}{|l|}{ Short-run } \\
\hline & $-0.2138752 * * *$ & $-.1787136^{*}$ & $-0.1692151^{*}$ & $-0.2034482^{*}$ & -0.1249898 \\
\hline & $(0.080)$ & $(0.106)$ & $(0.097)$ & $(0.115)$ & $(0.108)$ \\
\hline \multirow[t]{2}{*}{$\mathrm{IM}$} & $0.1575638^{*}$ & $0.170729 * * *$ & $0.1522926^{* * *}$ & $0.128304 * * *$ & $0.1148404 * * *$ \\
\hline & $(0.931)$ & $(0.039)$ & $(0.012)$ & $(0.032)$ & $(0.021)$ \\
\hline GDPP & $0.6503812 * * *$ & $0.5788987 * * *$ & $0.536378 * * *$ & $0.767384 * * *$ & $0.6000812 * *$ \\
\hline \multirow[t]{2}{*}{ FINRISK } & $(0.1233)$ & $\begin{array}{l}(0.149) \\
0.1721789 * *\end{array}$ & $(0.176)$ & $(0.255)$ & $(0.237)$ \\
\hline & & $(0.069)$ & & & \\
\hline RES & & $-0.0229442^{* *}$ & $-0.0217459 * *$ & $-0.019735^{* * *}$ & $-0.0204408 * *$ \\
\hline \multirow[t]{2}{*}{ ECORISK } & & $(0.010)$ & $\begin{array}{l}(0.010) \\
0.1024302 * * *\end{array}$ & $(0.007)$ & $(0.009)$ \\
\hline & & & $(0.009)$ & & \\
\hline \multirow[t]{2}{*}{ POLRISK } & & & & $-0.153500^{* * *}$ & \\
\hline & & & & $(0.049)$ & \\
\hline \multirow[t]{2}{*}{ COMRISK } & & & & & $0.1246875^{* * *}$ \\
\hline & & & & & $(0.025)$ \\
\hline \multicolumn{6}{|c|}{ Long Run Est. } \\
\hline \multirow[t]{2}{*}{$\operatorname{ECM}(-1)$} & $-0.83175^{* * *}$ & $-0.859810^{* * *}$ & $-0.902087^{* * *}$ & $-0.917964 * * *$ & $-0.8930572 * * *$ \\
\hline & $(0.086)$ & $(0.074)$ & $(0.091)$ & $(0.081)$ & $(0.087)$ \\
\hline \multirow[t]{2}{*}{ EX } & $-0.2107801 *$ & $-2.335891 *$ & $-0.283152 *$ & -0.1882974 & -0.1694072 \\
\hline & $(0.123)$ & $(0.131)$ & $(0.163)$ & $(0.184)$ & $(0.141)$ \\
\hline \multirow[t]{2}{*}{$\mathrm{IM}$} & 0.2062231 & $0.1937164 * * *$ & $0.1990075 * * *$ & $0.175965 * * *$ & $0.1505859 * * *$ \\
\hline & $(0.132)$ & $(0.025)$ & $(0.045)$ & $(0.041)$ & $(0.037)$ \\
\hline \multirow[t]{2}{*}{ GDPP } & $0.9343953 * * *$ & $0.6954528 * * *$ & $0.6570861 * * *$ & $0.848769 * * *$ & $0.80878^{* * *}$ \\
\hline & $(0.209)$ & $(0.194)$ & $(0.211)$ & $(0.318)$ & $(0.315)$ \\
\hline FINRISK & & $0.240114 * * *(0.089)$ & & & \\
\hline \multirow[t]{2}{*}{ RES } & & $-0.026633 * * *$ & $-0.0243312 * *$ & $-0.02159 * * *$ & $-0.0227449 * *$ \\
\hline & & $(0.010)$ & $(0.009)$ & $(0.007)$ & $(0.009)$ \\
\hline \multirow[t]{2}{*}{ ECORISK } & & & $0.1676883^{* * * *}$ & & \\
\hline & & & $(0.091)$ & & \\
\hline \multirow[t]{2}{*}{ POLRISK } & & & & $-0.177914 * * *$ & \\
\hline & & & & $(0.049)$ & \\
\hline \multirow[t]{2}{*}{ COMRISK } & & & & & $0.1389373 * * *$ \\
\hline & & & & & $(0.037)$ \\
\hline
\end{tabular}

Note: Asterisks denote the significance level of $10 \%(*), 5 \%(* *)$ and $1 \%(* * *)$ and the values in parentheses represent standard error 
case, the lower the risk and vice-versa. Several interesting interpretations are obtained based on results of Table 9 .

1) There is a significantly negative relationship between exports and $\mathrm{CCO}_{2}$. A one unit increase in exports caused $0.210 \%$ decrease in $\mathrm{CCO}_{2}$ emissions in long-run. In short-run, a $0.213 \%$ decrease in $\mathrm{CCO}_{2}$ is associated with a one unit increase in exports. A rational explanation to this result is that the top exports of RCEP economies are energy intensive products. For instance, in 2018, Australia exported coal briquettes worth $\$ 57$ billion US dollars, Japan exported vehicles worth $\$ 103$ billion, China exported broadcasting equipment worth $\$ 224$ billion, reported in Table 2. The export related findings are supportive of Ding et al. (2021); Hasanov et al. (2018); Safi et al. (2021) findings.

2) $\mathrm{A}$ one unit increase in imports upsurged $\mathrm{CCO}_{2}$ emissions by $0.206 \%$ in long-run, and the short-run results also supported this increase in $\mathrm{CCO}_{2}$ emissions by $0.157 \%$. Hence, a positive link is confirmed between imports and $\mathrm{CCO}_{2}$ emissions in RCEP economies. As petroleum is the top importing product in most of RCEP economies, it is obvious that machinery, industry and vehicles consumes the petroleum which adds into $\mathrm{CCO}_{2}$ emissions and further deteriorate environmental quality. Our results support the findings of Ali et al. (2020); Ding et al. (2021); Hasanov et al. (2018); Safi et al. (2021).

3) Further, the results indicate a positive association between GDP per-capita and $\mathrm{CCO}_{2}$ in long and short-run. To be specific, a one unit rise in GDP per-capita leads to $0.650 \%$ increase in $\mathrm{CCO}_{2}$ emissions in short-run, whereas in long-run, $0.934 \%$ decrease is caused by a one unit decrease in GDP per-capita. With the expansion in economic growth, economic activities upsurge that create opportunities and improve income level. Such expansions in economic structure are often assisted by energy consumption to fuel the domestic industry. Also, claimed by first stage of environmental Kuznet curve hypothesis EKC; economic growth or rise in income is associated with $\mathrm{CCO}_{2}$ emissions. The explanation is consistent with the findings of Al-mulali and Sheau-Ting (2014); Al Mamun et al. (2014); Bekun et al. (2019); Khan et al. (2020).

4) Next, a one unit increase in financial rating (FINRISK) is associated with $0.172 \%$ rise in $\mathrm{CCO}_{2}$ emissions in short-run, whereas in long-run $0.240 \%$ decrease is associated with a one unit decrease in financial risk rating. Hence, it implies that the lower financial risk in RCEP economies triggered $\mathrm{CCO}_{2}$ emissions. The sub-components of financial risk rating presented in Table 3 assess the ability of a country to finance its government activities. A logical explanation to this result is that financially less risky economies are more productive and able to attract more foreign capital and assist economic growth. Moreover, the flow of economic activities in less financial risky economy is more efficient and smoother as compared to high financial risky economies. These results are relevant and in line with findings of Safi et al. (2021) who reported that financial instability reduce $\mathrm{CCO}_{2}$ emissions in seven emerging economies. Nations and industries are spending less, consuming less energy and hence emitting less carbon emissions during financially instable situations.

5) Renewable energy supply (RES) is negatively associated with $\mathrm{CCO}_{2}$, implies that a $0.0022 \%$ decrease in $\mathrm{CCO}_{2}$ emissions is caused by a unit increase in renewable energy supply in short-run. The long-run results also support the short-run estimates, a $0.026 \%$ increase occurred in $\mathrm{CCO}_{2}$ emissions due to a one unit decrease in renewable energy supply. The supply or consumption of energy from cleaner resources (hydro, geothermal, solar, wind, combustible renewables, renewable waste) is associated with zero or less carbon emissions as compared to non-renewable sources (fossil fuels, etc.). These conclusions are consistent with the findings of Ali et al. (2020); Bekun et al. (2019); Destek and Aslan (2020); Hasanov et al. (2021); Liu et al. (2021); Saint Akadiri et al. (2019); Sharif et al. (2019); Ulucak and Khan (2020).

6) Economic risk (ECORISK) demonstrated a positive linkage with $\mathrm{CCO}_{2}$, a $0.102 \%$ increase is caused by a one unit increase in economic risk rating in short-run. Besides, in long-run a $0.167 \%$ decrease is generated by a one unit decrease in $\mathrm{CCO}_{2}$ emissions. Therefore, the lower economic risk in RCEP economies is associated with more $\mathrm{CCO}_{2}$ emissions. The sub-components of economic risk collectively determine strengths and weaknesses of an economy and are reported in Table 3. Generally, where strengths exceed its weaknesses, it will present a low economic risk and weaknesses exceed strengths will present a high economic risk. The lower GDP growth, GDP per-capita and higher price volatility create uncertainty that discourage the investment projects and consumptions and ultimately lead to less energy consumption and less emissions (Ahmad et al. 2020).

7) A significantly negative association is found between political risk (POLRISK) and $\mathrm{CCO}_{2}$ emissions in short- and long-run. A $0.153 \%$ decrease in $\mathrm{CCO}_{2}$ emissions is caused by a unit increase in political risk in short-run. On the other hand, a unit increase in political risk causes $0.177 \%$ decrease in $\mathrm{CCO}_{2}$ emissions in the long-run. Hence, it implies that most of RCEP economies are less political risky, that result in less $\mathrm{CCO}_{2}$ emissions. The political risk index assesses the stability of political system of a country that comprises of 12 sub-components presented in Table 3. The higher the political risk rating points, the more stable an economy is, which implies government stability, better socioeconomic conditions, healthy investment profile, no or less political violence, 
no or less external conflicts, zero or few corrupt officials in government, uninvolved military in politics, no or less religious tensions, effective law and order, no or less ethnic tensions, responsive government (democratic accountability), and high bureaucracy quality. An economy with improved previously mentioned characteristics will have less $\mathrm{CCO}_{2}$ emissions. For example, more corruption could weaken environmental regulations that leads to illegal production and consumption which eventually rise carbon emissions and deteriorate environmental quality (Chen et al. 2018). Similarly, Zhou et al. (2020) found that an anti-corruption campaign reduce corruption and consequently reduce environmental pollution. Furthermore, the strength of institution quality plays a vital role in safeguarding environmental quality by imposing strict regulations that discourage illegal emissions by imposing penalties on such unlawful activities (Ali et al. 2019; Khan et al. 2020).

8) The composite risk rating, which is the aggregate of previously mentioned three risks (financial, economic and political risk) is designed by the formula represented as " $A$ " according to international country risk guide database (ICRG). There is a significantly positive relationship between composite risk and $\mathrm{CCO}_{2}$ emissions. A $0.124 \%$ increase in $\mathrm{CCO}_{2}$ emissions is resulted by a one unit increase in composite risk in short-run. Similarly, $0.138 \%$ decrease in $\mathrm{CCO}_{2}$ is caused by a one unit decrease in composite risk. The lower the composite risk, the more $\mathrm{CCO}_{2}$ emissions. A logical explanation to this positive relationship is that the two sub-components (financial risk and political risk) of composite risk depict positive relationship while only political risk shows negative relationship in all the models. Hence, it is obvious that the two positive relationships (economic risk and financial risk) outweighed the negative relationship of political risk with $\mathrm{CCO}_{2}$ emissions while considering the composite risk index, which eventually result in a positive relationship between composite risk and $\mathrm{CCO}_{2}$ emissions in RCEP economies.

As this is the first study to investigate the relationship of financial, economic, political and composite risk with $\mathrm{CCO}_{2}$ emissions in selected RCEP economies, hence we cannot compare our results with the findings of previous studies. However, some recent studies considered substitute or alternatives of these risk rating, for instance, Safi et al. (2021) concluded that financial instability, exports and technological innovations reduce $\mathrm{CCO}_{2}$ emissions significantly in seven emerging economies. Zhang (2011) reported that financial development act as major driver for increase in carbon emission in China.

\section{Dumitrescu-Hurlin panel causality}

To examine the causal relationship between the observed variables, this study employed Dumitrescu-Hurlin (2012) panel causality test. The test results reported in Table 10 report that there is a bi-directional causality between exports and $\mathrm{CCO}_{2}$ emissions, imports and $\mathrm{CCO}_{2}$ emissions, GDP per-capita and $\mathrm{CCO}_{2}$ emissions, political risk and $\mathrm{CCO}_{2}$ emissions, economic risk and $\mathrm{CCO}_{2}$ emissions, and renewable energy supply and $\mathrm{CCO}_{2}$ emissions. Any shock to $\mathrm{CCO}_{2}$ emissions has significant implications for exports, imports, GDPP, political risk, and renewable energy supply in RCEP economies. A unidirectional causality running from financial risk to $\mathrm{CCO}_{2}$ emissions, economic risk to $\mathrm{CCO}_{2}$ emissions, and composite risk to $\mathrm{CCO}_{2}$ emissions is found in these economies. The results support the findings of Ali et al. (2020); Bekun et al. (2019); Saint Akadiri et al. (2019).

\section{Robustness analysis}

For robustness check, we employed Augmented Mean Group estimation to check the validity of our previously mentioned empirical analyses. The robustness analysis reported in Table 11, confirmed that exports, renewable energy supply, less political risk are associated with less $\mathrm{CCO}_{2}$ emissions. Whereas, imports, GDPP, less financial risk, less economic risk and less composite risk factors are causing a surge in $\mathrm{CCO}_{2}$ emissions in selected RCEP economies.

\section{Discussion on the contributions of economic, financial and political risk}

Beside exports, imports and GDP per-capita, the main focus of the present investigation is to examine the role financial, economic, political and composite risk in consumption-based carbon dioxide emissions in RCEP economies. The positive and significant coefficient of financial, economic and composite risk implies that the higher the risk rating values, the lower the risk in every case, which implies the more $\mathrm{CCO}_{2}$ emissions, whereas, the negatively significant coefficient of political risk suggests that the lower political risk is associated with less $\mathrm{CCO}_{2}$ emissions.

Most of the RCEP economies, for instance Australia, Japan, China, Korea, Rep., New Zealand and Singapore depict moderate or low financial and economic risks according to the data obtained from International Country Risk Guide (ICRG) dataset. The lower financial and economic risks in these economies also imply the lower composite risk, which is the aggregate of economic, financial and political risk. In general, less financial and economic risky economies are more productive and operate efficiently due to high per-capita income, high economic growth rate, less or zero foreign debt, stable exchange rates and 
Table 10 Pairwise Dumitrescu-Hurlin Panel Causality Tests (2012)

\begin{tabular}{|c|c|c|c|c|}
\hline & Nature of causality & W-Stats. & Zbar-Stat. & Prob. \\
\hline Ex & $\Rightarrow \mathrm{CCO}_{2}$ & $3.56323 * * *$ & 5.07167 & 0.000 \\
\hline $\mathrm{CCO}_{2}$ & EX & $3.79789 * * *$ & 5.55094 & 0.000 \\
\hline $\mathrm{IM}$ & $\mathrm{CCO}_{2}$ & $2.84348 * * *$ & 3.60168 & 0.0003 \\
\hline $\mathrm{CCO}_{2}$ & $\mathrm{IM}$ & $3.39312 * * *$ & 4.72425 & 0.000 \\
\hline GDPP & $\mathrm{CCO}_{2}$ & $3.19790 * * *$ & 4.32555 & 0.000 \\
\hline $\mathrm{CCO}_{2}$ & GDPP & $2.36544 * * *$ & 2.62535 & 0.0087 \\
\hline POLRISK & $\mathrm{CCO}_{2}$ & $3.14022 * * *$ & 4.20774 & 0.000 \\
\hline $\mathrm{CCO}_{2}$ & POLRISK & $3.04441 * * *$ & 4.01206 & 0.000 \\
\hline FINRISK & $\mathrm{CCO}_{2}$ & $3.25411 * * *$ & 3.35559 & 0.000 \\
\hline $\mathrm{CCO}_{2}$ & FINRISK & 1.10356 & 0.04811 & 0.9616 \\
\hline ECORISK & $\mathrm{CCO}_{2}$ & $4.27781 * * *$ & 3.40400 & 0.000 \\
\hline $\mathrm{CCO}_{2}$ & ECORISK & 1.23153 & 0.30947 & 0.7570 \\
\hline COMRISK & $\mathrm{CCO}_{2}$ & $2.09023 * *$ & 2.06327 & 0.0391 \\
\hline $\mathrm{CCO}_{2}$ & COMRISK & 1.41646 & 0.68717 & 0.4920 \\
\hline RES & $\mathrm{CCO}_{2}$ & $3.07338 * * *$ & 4.07123 & 0.000 \\
\hline $\mathrm{CCO}_{2}$ & RES & $5.05740 * * *$ & 8.12332 & 0.000 \\
\hline
\end{tabular}

Note: Asterisks denote a significance level of $10 \%(*), 5 \%(* *)$ and $1 \%(* * *)$

investment of foreign capital. Collectively, all these factors provide a favorable environment for economic activities to expand. The higher income and growing economic activities mean more investment projects, more production, more consumption that eventually leads to more carbon emissions in RCEP economies. Furthermore, the negatively significant coefficient of political risk implies that, the higher the political risk rating value, the lower the risk, which resulted in less $\mathrm{CCO}_{2}$ emissions in RCEP economies. Hence, it is rational to state that the less political risk in these economies has significantly mitigated $\mathrm{CCO}_{2}$ emission.

\section{Conclusion and policy implications}

Considering the literary studies on the climate change and environmental pollution, this study adds to the present literature by examining the impact of financial, economic, political and composite risk along with the role of renewable energy supply on consumption-based carbon dioxide emissions $\left(\mathrm{CCO}_{2}\right)$ in the selected RCEP economies for the period of 1990-2020. The empirical contribution of this study to the existing literature is testing the role of financial, economic, political and composite risks in $\mathrm{CCO}_{2}$ emissions in selected RCEP economies. Moreover, the present study also

Table 11 Robustness analysis (Augmented Mean Group estimation)

Dependent variable: $\mathrm{CCO}_{2}$

\begin{tabular}{|c|c|c|c|c|c|}
\hline Variables & Model-1 & Model-2 & Model-3 & Model-4 & Model-5 \\
\hline EX & $-0.302 * * *$ & $-0.197^{*}$ & $-0.208 *$ & $-0.256^{* *}$ & $-0.168 * * *$ \\
\hline IM & $0.195 *$ & $0.096^{* * *}$ & $0.096 * * *$ & $0.121 * * *$ & $0.104 * * *$ \\
\hline GDPP & $0.842 * * *$ & $0.709 * * *$ & $0.814 * * *$ & $0.907 * * *$ & $0.870 * * *$ \\
\hline FINRISK & & $0.097 *$ & & & \\
\hline RES & & $-0.267 * * *$ & $-0.245 * * *$ & $-0.241 * * *$ & $-0.265 * * *$ \\
\hline ECORISK & & & $0.058 * * *$ & & \\
\hline POLRISK & & & & $-0.170 * * *$ & \\
\hline COMRISK & & & & & $0.137 * *$ \\
\hline
\end{tabular}

Note: Asterisks denote a significance level of $10 \%(*), 5 \%(* *)$ and $1 \%(* * *)$ 
considered exports and imports individually along with the role of renewable energy supply.

The econometric approaches used in the study provide robust estimated results: (I) The issue of slope heterogeneity is confirmed in all five models: (II) The result supports the presence of cross-sectional dependency; (III) The observed variables are integrated of order one except ECORISK, which is I (0); (IV) Co-integration relationship is confirmed among the observed variables; (V) Exports, imports, GDP per-capita, financial risk, economic risk, political risk, composite risk and renewable energy supply are important factors explaining $\mathrm{CCO}_{2}$ emissions; (VI) the hypothesized linkage of risk rating (financial risk, economic risk, political risk and composite risk) and other variables (exports, imports and renewable energy supply) with $\mathrm{CCO}_{2}$ is validated by the lingering value of ECT; (VII) the lower financial, economic political and composite risk is associated with more $\mathrm{CCO}_{2}$ emissions while the lower political risk help to mitigate $\mathrm{CCO}_{2}$ emissions; (VIII) exports decrease while imports adds into $\mathrm{CCO}_{2}$ emissions; (IX) renewable energy supply limit $\mathrm{CCO}_{2}$ emissions; (X) rise in GDP per-capita deteriorates environmental quality; (XI) evidence of bi-directional causality between exports and $\mathrm{CCo}_{2}$ emissions, imports and $\mathrm{CCO}_{2}$ emissions, GDP per-capita and $\mathrm{CCO}_{2}$ emissions, political risk and $\mathrm{CCO}_{2}$ emissions, economic risk and $\mathrm{CCO}_{2}$ emissions, and renewable energy supply and $\mathrm{CCO}_{2}$ emissions; (XII) there are unidirectional causalities running form financial risk to $\mathrm{CCO}_{2}$ emissions, economic risk to $\mathrm{CCO}_{2}$ emissions, composite risk to $\mathrm{CCO}_{2}$ emissions; and (XIII) any change of policy in financial risk, economic risk and composite risk has implications for $\mathrm{CCO}_{2}$ emissions. The current study advances our understanding of $\mathrm{CCO}_{2}$ emissions by incorporation of four different types of risk factors of an economy. In specific, less financial, economic and composite risky economies along with increase in imports and per-capita income results in more $\mathrm{CCO}_{2}$. Whereas, less political risk, exports and renewable energy supply helps to mitigate $\mathrm{CCO}_{2}$ emissions in selected economies.

Based on estimated results, the policy implication of this study suggests that (a) focusing on climate change and environmental degradation issues, it is rational to consider consumption-based measurement approach for carbon emission as it comprehensively captures the emissions along entire carbon chain which is significant to understand the global struggle for climate change and environmental degradation; (b) To tackle the issue of $\mathrm{CCO}_{2}$ emissions, a serious consideration is required on the role of renewable energy supply, which is obvious from our estimates that mitigate $\mathrm{CCO}_{2}$ emissions significantly in RCEP economies; c) The strict environmental policies along with penalties for illegal emissions, corruption control, government stability and democratic accountability, institutional quality and strong law and order would assist to limit $\mathrm{CCO}_{2}$ emission and achieve the goals of carbon neutrality agenda in long-run in these economies.
In order to further enlighten the global issue of consumption-based carbon dioxide emissions, it will be interesting to empirically investigate the impact of economic complexity index, availability of natural resources and domestic energy demand on consumption-based carbon dioxide emissions.

Author contribution The idea of the original draft belongs to Taimoor Hassan and Huaming Song. The introduction, literature review and empirical outcomes sections are written by Taimoor Hassan. Dervis Kirikkaleli constructed the methodology section in the study. All the authors read and approved the final manuscript.

Data availability The data for this study is available on World Bank (WB) website, international country risk guide, OEC website and global carbon atlas website. The data used in this study is from 1990-2018. The data for last two years (2019 and 2020) were generated based on previous data.

\section{Declarations}

Ethics approval and consent to participate We confirmed that this manuscript has not been published elsewhere and is not under consideration by another journal. Ethical approval and Informed consent do not applicable for this study.

Consent for publication Not applicable

Conflict of interest The authors declare no competing interests.

\section{References}

Abbasi K, Jiao Z, Shahbaz M, Khan A (2020) Asymmetric impact of renewable and non-renewable energy on economic growth in Pakistan: new evidence from a nonlinear analysis. Energy Explor Exploit 38(5):1946-1967

Abbasi KR, Abbas J, Mahmood S, Tufail M (2021a) Revisiting electricity consumption, price, and real GDP: a modified sectoral level analysis from Pakistan. Energy Policy 149:112087

Abbasi KR, Shahbaz M, Jiao Z, Tufail M (2021b) How energy consumption, industrial growth, urbanization, and $\mathrm{CO}_{2}$ emissions affect economic growth in Pakistan? A novel dynamic ARDL simulations approach. Energy 221:119793

Acaravci A, Ozturk I (2010) On the relationship between energy consumption, $\mathrm{CO}_{2}$ emissions and economic growth in Europe. Energy 35(12):5412-5420

Ahmad, W., Ullah, S., Ozturk, I., \& Majeed, M. T. (2020). Does inflation instability affect environmental pollution? Fresh evidence from Asian economies. Energy Environ 0958305X20971804.

Al Mamun M, Sohag K, Mia MAH, Uddin GS, Ozturk I (2014) Regional differences in the dynamic linkage between $\mathrm{CO}_{2}$ emissions, sectoral output and economic growth. Renew Sust Energ Rev 38:1-11

Ali HS, Zeqiraj V, Lin WL, Law SH, Yusop Z, Bare UAA, Chin L (2019) Does quality institutions promote environmental quality? Environ Sci Pollut Res 26(11):10446-10456

Ali, S., Dogan, E., Chen, F., \& Khan, Z. (2020). International trade and environmental performance in top ten-emitters countries: the role of eco-innovation and renewable energy consumption. Sustain Dev. 
Al-Mulali U, Ozturk I (2015) The effect of energy consumption, urbanization, trade openness, industrial output, and the political stability on the environmental degradation in the MENA (Middle East and North African) region. Energy 84:382-389

Al-mulali U, Sheau-Ting L (2014) Econometric analysis of trade, exports, imports, energy consumption and $\mathrm{CO}_{2}$ emission in six regions. Renew Sust Energ Rev 33:484-498

Al-Mulali U, Ozturk I, Solarin SA (2016) Investigating the environmental Kuznets curve hypothesis in seven regions: the role of renewable energy. Ecol Indic 67:267-282

Balsalobre-Lorente, D., Shahbaz, M., Ponz-Tienda, J. L., \& CantosCantos, J. M. (2017). Energy innovation in the environmental Kuznets curve (EKC): a theoretical approach Carbon footprint and the industrial life cycle (pp. 243-268): Springer.

Bednar-Friedl B, Schinko T, Steininger KW (2012) The relevance of process emissions for carbon leakage: a comparison of unilateral climate policy options with and without border carbon adjustment. Energy Econ 34:S168-S180

Bekun FV, Alola AA, Sarkodie SA (2019) Toward a sustainable environment: Nexus between $\mathrm{CO}_{2}$ emissions, resource rent, renewable and nonrenewable energy in 16-EU countries. Sci Total Environ 657:1023-1029

Bhattacharya M, Inekwe J, Paramati SR (2018) Remittances and financial development: empirical evidence from heterogeneous panel of countries. Appl Econ 50(38):4099-4112

Chen H, Hao Y, Li J, Song X (2018) The impact of environmental regulation, shadow economy, and corruption on environmental quality: theory and empirical evidence from China. J Clean Prod 195:200 214

Chudik A, Pesaran MH (2015) Common correlated effects estimation of heterogeneous dynamic panel data models with weakly exogenous regressors. J Econ 188(2):393-420

Chudik A, Mohaddes K, Pesaran MH, Raissi M (2017) Is there a debtthreshold effect on output growth? Rev Econ Stat 99(1):135-150

Cole MA (2004) Trade, the pollution haven hypothesis and the environmental Kuznets curve: examining the linkages. Ecol Econ 48(1):7181

Cole MA, Elliott RJ (2003) Determining the trade-environment composition effect: the role of capital, labor and environmental regulations. $J$ Environ Econ Manag 46(3):363-383

Davis SJ, Caldeira K (2010) Consumption-based accounting of $\mathrm{CO}_{2}$ emissions. Proc Natl Acad Sci 107(12):5687-5692

Destek MA, Aslan A (2020) Disaggregated renewable energy consumption and environmental pollution nexus in G-7 countries. Renew Energy 151:1298-1306

Ding Q, Khattak SI, Ahmad M (2021) Towards sustainable production and consumption: assessing the impact of energy productivity and eco-innovation on consumption-based carbon dioxide emissions (CCO2) in G-7 nations. Sustain Product Consump 27:254-268

Dumitrescu E-I, Hurlin C (2012) Testing for Granger non-causality in heterogeneous panels. Econ Model 29(4):1450-1460

Eskeland GS, Harrison AE (2003) Moving to greener pastures? Multinationals and the pollution haven hypothesis. $J$ Dev Econ 70(1):1-23

Farhani S, Mrizak S, Chaibi A, Rault C (2014) The environmental Kuznets curve and sustainability: A panel data analysis. Energy Policy 71:189-198

Fernández-Amador O, Francois JF, Oberdabernig DA, Tomberger P (2017) Carbon dioxide emissions and economic growth: an assessment based on production and consumption emission inventories. Ecol Econ 135:269-279

Frankel JA, Rose AK (2005) Is trade good or bad for the environment? Sorting out the causality. Rev Econ Stat 87(1):85-91

Hasanov FJ, Liddle B, Mikayilov JI (2018) The impact of international trade on $\mathrm{CO}_{2}$ emissions in oil exporting countries: territory vs consumption emissions accounting. Energy Econ 74:343-350
Hasanov FJ, Khan Z, Hussain M, Tufail M (2021) Theoretical framework for the carbon emissions effects of technological progress and renewable energy consumption. Sustain Dev

Heil MT, Selden TM (2001) International trade intensity and carbon emissions: a cross-country econometric analysis. J Environ Dev 10(1):35-49

Hossain MS (2011) Panel estimation for $\mathrm{CO}_{2}$ emissions, energy consumption, economic growth, trade openness and urbanization of newly industrialized countries. Energy Policy 39(11):6991-6999

Iqbal N, Abbasi KR, Shinwari R, Guangcai W, Ahmad M, Tang K (2021) Does exports diversification and environmental innovation achieve carbon neutrality target of OECD economies? J Environ Manag 291:112648

Issik C, Ahmad M, Pata UK, Ongan S, Radulescu M, Adedoyin FF, Bayraktaroğlu E, Aydın S, Ongan A (2020) An evaluation of the tourism-induced environmental Kuznets curve (T-EKC) hypothesis: evidence from G7 Countries. Sustainability 12(21):9150

Karakaya E, Yılmaz B, Alataş S (2019) How production-based and consumption-based emissions accounting systems change climate policy analysis: the case of $\mathrm{CO}_{2}$ convergence. Environ Sci Pollut Res 26(16):16682-16694

Katircioglu, S., Köksal, C., \& Katircioglu, S. (2021). The role of financial systems in energy demand: a comparison of developed and developing countries. Heliyon, e 07323

Khan Z, Ali S, Umar M, Kirikkaleli D, Jiao Z (2020) Consumption-based carbon emissions and international trade in G7 countries: the role of environmental innovation and renewable energy. Sci Total Environ 730:138945

Khan Z, Ali S, Dong K, Li RYM (2021) How does fiscal decentralization affect $\mathrm{CO}_{2}$ emissions? The roles of institutions and human capital. Energy Econ 94:105060

Knight KW, Schor JB (2014) Economic growth and climate change: a cross-national analysis of territorial and consumption-based carbon emissions in high-income countries. Sustainability 6(6):3722-3731

Köksal C, Işik M, Katircioğlu S (2020) The role of shadow economies in ecological footprint quality: empirical evidence from Turkey. Environ Sci Pollut Res 27(12):13457-13466

Köksal C, Katircioglu S, Katircioglu S (2021) The role of financial efficiency in renewable energy demand: evidence from OECD countries. J Environ Manage 285:112122

Lau L-S, Choong C-K, Eng Y-K (2014) Carbon dioxide emission, institutional quality, and economic growth: empirical evidence in Malaysia. Renew Energy 68:276-281

Liddle B (2018) Consumption-based accounting and the trade-carbon emissions nexus in Asia: A heterogeneous, common factor panel analysis. Sustainability 10(10):3627

Liu J, Murshed M, Chen F, Shahbaz M, Kirikkaleli D, Khan Z (2021) An empirical analysis of the household consumption-induced carbon emissions in China. Sustain Product Consump 26:943-957

Managi, S., Hibiki, A., \& Tsurumi, T. (2008). Does trade liberalization reduce pollution emissions. Discussion papers, 8013

Nathaniel S, Khan SAR (2020) The nexus between urbanization, renewable energy, trade, and ecological footprint in ASEAN countries. $J$ Clean Prod 272:122709

Ozturk I, Acaravci A (2013) The long-run and causal analysis of energy, growth, openness and financial development on carbon emissions in Turkey. Energy Econ 36:262-267

Pesaran MH (2004) General diagnostic tests for cross-sectional dependence in panels. Empir Econ:1-38

Pesaran MH (2007) A simple panel unit root test in the presence of crosssection dependence. J Appl Econ 22(2):265-312

Pesaran MH, Yamagata T (2008) Testing slope homogeneity in large panels. J Econ 142(1):50-93

Peters, G. P., \& Hertwich, E. G. (2008). $\mathrm{CO}_{2}$ embodied in international trade with implications for global climate policy: ACS Publications 
Peters GP, Aamaas B, Berntsen T, Fuglestvedt JS (2011) The integrated global temperature change potential (iGTP) and relationships between emission metrics. Environ Res Lett 6(4):044021

Peters GP, Davis SJ, Andrew R (2012) A synthesis of carbon in international trade. Biogeosciences 9(8):3247-3276

Radulescu M, Fedajev A, Sinisi CI, Popescu C, Iacob SE (2018) Europe 2020 implementation as driver of economic performance and competitiveness. Panel analysis of CEE countries. Sustainability 10(2): 566

Rothman DS (1998) Environmental Kuznets curves - real progress or passing the buck?: A case for consumption-based approaches. Ecol Econ 25(2):177-194

Safi A, Chen Y, Wahab S, Ali S, Yi X, Imran M (2021) Financial instability and consumption-based carbon emission in E-7 countries: the role of trade and economic growth. Sustain Product Consump 27: 383-391

Saint Akadiri S, Alola AA, Akadiri AC, Alola UV (2019) Renewable energy consumption in EU-28 countries: policy toward pollution mitigation and economic sustainability. Energy Policy 132:803-810

Scott K, Barrett J (2015) An integration of net imported emissions into climate change targets. Environ Sci Pol 52:150-157

Seker, F., Cetin, M., Topcu, B., Seren, G. Y. (2015) Relationships between financial development, trade openness, and economic growth: empirical evidence for Turkey Regional Economic Integration and the Global Financial System (pp. 183-196): IGI Global

Shahbaz M, Nasreen S, Ahmed K, Hammoudeh S (2017) Trade openness-carbon emissions nexus: the importance of turning points of trade openness for country panels. Energy Econ 61:221-232
Shahzad SJH, Kumar RR, Zakaria M, Hurr M (2017) Carbon emission, energy consumption, trade openness and financial development in Pakistan: a revisit. Renew Sust Energ Rev 70:185-192

Sharif A, Raza SA, Ozturk I, Afshan S (2019) The dynamic relationship of renewable and nonrenewable energy consumption with carbon emission: a global study with the application of heterogeneous panel estimations. Renew Energy 133:685-691

Spaiser V, Scott K, Owen A, Holland R (2019) Consumption-based accounting of $\mathrm{CO}_{2}$ emissions in the sustainable development Goals Agenda. Int J Sustain Dev World Ecol 26(4):282-289

Tamiotti, L. (2009) Trade and climate change: a report by the United Nations Environment Programme and the World Trade Organization: UNEP/Earthprint

Tufail M, Song L, Adebayo TS, Kirikkaleli D, Khan S (2021) Do fiscal decentralization and natural resources rent curb carbon emissions? Evidence from developed countries. Environ Sci Pollut Res:1-12

Ulucak R, Khan SU-D (2020) Determinants of the ecological footprint: role of renewable energy, natural resources, and urbanization. Sustain Cities Soc 54:101996

Westerlund J (2007) Testing for error correction in panel data. Oxf Bull Econ Stat 69(6):709-748

Zhang Y-J (2011) The impact of financial development on carbon emissions: an empirical analysis in China. Energy Policy 39(4):21972203

Zhou M, Wang B, Chen Z (2020) Has the anti-corruption campaign decreased air pollution in China? Energy Econ 91:104878

Publisher's note Springer Nature remains neutral with regard to jurisdictional claims in published maps and institutional affiliations. 